Cahiers $d u$ MONDE RUSSE

\section{Cahiers du monde russe}

Russie - Empire russe - Union soviétique et États indépendants

$52 / 1 \mid 2011$

Varia

\title{
For love and fatherland: Political clientage and the Origins of Russia's first female order of chivalry
}

Pour l'amour et la patrie: le clientélisme politique et les origines du premier ordre russe de chevalerie pour les femmes

Igor Fedyukin et Ernest A. Zitser

\section{(2) OpenEdition}

Journals

Édition électronique

URL : https://journals.openedition.org/monderusse/9320

DOI : $10.4000 /$ monderusse. 9320

ISSN : $1777-5388$

Éditeur

Éditions de l'EHESS

Édition imprimée

Date de publication : 5 mars 2011

Pagination : 5-44

ISBN : $978-2-7132-2351-8$

ISSN : $1252-6576$

Référence électronique

Igor Fedyukin et Ernest A. Zitser, «For love and fatherland : Political clientage and the Origins of Russia's first female order of chivalry ", Cahiers du monde russe [En ligne], 52/1 | 2011, mis en ligne le 28 mars 2014, consulté le 03 septembre 2022. URL : http://journals.openedition.org/monderusse/ 9320 ; DOl : https://doi.org/10.4000/monderusse.9320

Ce document a été généré automatiquement le 3 septembre 2022

Tous droits réservés 


\section{For love and fatherland : Political clientage and the Origins of Russia's first female order of chivalry}

Pour l'amour et la patrie : le clientélisme politique et les origines du premier ordre russe de chevalerie pour les femmes

Igor Fedyukin et Ernest A. Zitser

\section{NOTE DE L'AUTEUR}

The authors wish to thank Gary Marker (SUN Y-Stony Brook), the anonymous reviewers at the Cahiers, as well as the organizers and participants of the seminars held at the European University in St. Petersburg and the Higher School of Economics (Moscow) for all their comments and suggestions. Igor Fedyukin also gratefully acknowledges the support provided by the Bourse Diderot, Foundation Maison des Sciences de l'Homme.

1 Thanks in large part to the pioneering work of Richard Wortman, the focus of recent studies of Russian court culture has shifted from analyzing the semiotics of royal splendor to establishing who was actually responsible for composing the "scenarios of power" that sought to "elevate" a particular representative of the Romanov dynasty and what their reasons were for doing so. ${ }^{1}$ Recognizing the dangers of generalizing too grandly about the role of Russian autocrats in determining the cultural agendas of their day, even in so intimate a sphere of activity as royal self-presentation, historians have struggled with the question of how to write about court pageantry and scriptcomposition as elements of an on-going process, that is, as an unequal negotiation through which political authority is constructed, implemented, and contested by individuals and patron-client groups seeking to monopolize access to, and "divine" the will of the tsar. ${ }^{2}$ Following this line of inquiry, the present article offers a concrete test case of the proposition that political ritual can be analyzed not simply in terms of symbolic meaning, but also in terms of what its creation can tell us about networks of 
patronage and power at the Russian Imperial court. The specific topic under study is the foundation of the Order of St. Catherine, or Deliverance, the second-oldest chivalrous knightly order in the new system of honors introduced to Russia during the reign of Peter I the Great (1689-1725), and the only one reserved exclusively for women. ${ }^{3}$ This historical topic was selected, at least in part, because it concerns the reign of a tsar whose name has become synonymous with both "cultural revolution" and "totalitarian" micromanagement. ${ }^{4}$ It thus provides a strong test case for assessing the viability of the interdisciplinary approach adopted by the authors of the present article - an approach that is situated at the intersection of microhistory, gender studies, and semiotics, and that has many points of contact with the "new political history."

2 As Lindsey Hughes, Gary Marker, and others have noted, the creation of the Order of St. Catherine was only one element in a long chain of ceremonial events - from the staging of "The St. Catherine Play" sometime after 1707 to the tsar's public wedding ceremony in 1712 - that progressively established the legitimacy of Peter's children by his former mistress and that laid the ground for her own coronation as empress in $1724 .{ }^{6}$ In the context of an early-modern dynastic monarchy like Russia, these developments were, obviously, of crucial political importance, especially insofar as they were intertwined with the disinheritance, trial, and death of Tsarevich Aleksei (1690-1718), Peter's firstborn son and presumptive heir. It is quite natural, therefore, to assume, as scholars have traditionally done, that the Order of St. Catherine was conceived, designed, and established by Peter himself. Although until now the authorship of the Order's statutes has remained unknown, the scholarly consensus has been that this document bears "a trademark of Peter's sense of the indivisibility of church and state" and that it "provides considerable insight into Peter's intentions." " Indeed, given the crucial importance of the cult of St. Catherine to Peter's dynastic policy, as well as the emperor's legendary, almost obsessive attention to the details of his pet projects, it could not have been otherwise. ${ }^{9}$

3 However, thanks to a number of new archival discoveries, we are in a position to highlight the role that actors other than Peter - most notably the tsar's low-born, second wife, Tsaritsa Catherine Alekseevna (née Marta Skavronskaia, 1682/4-1727), ${ }^{10}$ and his pedigreed former brother-in-law (svoiak), Prince Boris Ivanovich Kurakin (1676-1727) ${ }^{11}$ played in instituting the Order of St. Catherine. Reconstructing a dialog around the correspondence between Kurakin and Catherine, who personally commissioned the diplomat to draft a project for the order, will allow us to demonstrate that (contrary to standing supposition) the evidence for Peter I's direct involvement in the project is slight; whereas Catherine, Kurakin, and people under their supervision worked carefully and thoughtfully on the idea's fulfillment. As a result, the project as it emerged was both their creation (largely) and a means by which they simultaneously built their own political and cultural capital. Needless to say, these elite political actors did not act against Peter's wishes, or without his knowledge and approval. Rather, the tsar's overall interest in orders of chivalry and in raising Catherine's profile provided a broad framework that enabled individual actors to pursue their own personal agendas by pushing the project forward.

Three previously-unpublished documents from the manuscript division of the State Historical Museum in Moscow allow us to shed a new light on the origins and political significance of the Order of St. Catherine..$^{12}$ All three documents come from a leather- 
bound volume of miscellaneous papers in the Kurakin Family Collection, only a fraction of which was published by the editors of the massive, ten-volume Arkhiv kn. F.A. Kurakina..$^{13}$ Two of these documents contain the identical French text, entitled "Project d'un ordre de Chevalerie qui pouvoit etre institute en faveur des Dames a la Cour de sa maj. ${ }^{\text {te }}$ Czarienne." Both are written on early-eighteenth-century paper and bear the same watermarks ("Amsterdam Arms") and countermarks (the letters VT, denoting the initials of the surname and Christian name of the papermaker). ${ }^{14}$ One is a rough draft, with a few minor corrections; ${ }^{15}$ the other - a clean copy, written in what looks like a professional scribe's hand. ${ }^{16}$ On the reverse side of the last page, the latter document contains a barely decipherable Russian note, which reads: "This is submitted via Mr. Du [illegible-eds.] (sie dano chrez gdna Du<...) July 20/31 in The Hague." The same volume also includes an undated and unsigned Russian manuscript, entitled "Proekt ob ordene kavalerii kotoroi mozhet uchrezhden byt' pri dvore ego tsarskogo velichestva." ${ }^{17}$ This is the translation of the French document, executed by two different employees of the chancellery of Prince Kurakin, who since October 1712 served as the Russian ambassador to the United Provinces. The text of the translation is situated in the right half of each of the pages, with the left half reserved for subsequent corrections. Numerous corrections are indeed provided, both by the original Russian translators and, on top of those, by Prince Kurakin himself, in his distinctive and barely-legible handwriting. ${ }^{18}$

Significantly, the document corrected by Kurakin is nearly identical to the text we know as the official statutes of the Order of St Catherine, which were first published in October 1713 by the St. Petersburg Typography, ${ }^{19}$ and later reprinted by N.N. BantyshKamenskii ${ }^{20}$ and the compilers of the Complete Collection of Laws of the Russian Empire. ${ }^{21}$ According to the embassy's official record of all incoming and outgoing diplomatic correspondence (protokol'naia kniga), the Russian translation of the French project was sent by diplomatic pouch on 25 August $1713{ }^{22}$ The statutes were actually just one of the enclosures in Kurakin's missive to the head of the Foreign Affairs Chancellery, Count G.I. Golokvin, who was specifically instructed to "deliver the enclosed [materials], which include the [badge of the] Order that was commissioned by royal decree, to the Sovereign Tsaritsa" (prilozhennoe gosudaryne tsaritse vruchit', $v$ kotorom ordin posylaetsia po ukazu sdelannyi). ${ }^{23}$ Golovkin acknowledged receipt of this letter and its enclosures on 30 September, but did not specifically mention the Order or its statutes, announcing merely that he "conveyed what needed to be reported about them to His Tsarist Majesty [Peter]" (chto nadlezhalo po onym, ego tsarskomu velichestvu donosil). ${ }^{24}$ Judging by the fact that Catherine's reply was also dated 30 September 1713, Golovkin must have immediately passed Kurakin's package on to her. Whether or not Peter knew anything about this project, he appears not to have had any time to edit the document that was ostensibly so crucial for his dynastic strategy: the Statutes of the Order of St. Catherine went to press as received from The Hague.

The cover letter that accompanied Kurakin's package deserves to be quoted in full because it represents the best piece of evidence that we currently possess about the motives of the individuals involved in the creation of the Order of St. Catherine: ${ }^{25}$

Although there was a delay in founding the Order (uchinenii ordina) that I had been authorized to make by Your Majesty's decree (kak ukazom vashego velichestva mne bylo poveleno sdelat'), - which, needless to say, demanded quite a lot of time, not only for coming up with the idea for it, but also for designing what it would look like, composing its motto, as well formulating its regulations, and everything in such a way that all these aspects were interlinked and in accord with the true 
history of the deed itself, that being the very basis for reviving this order in Europe, as well as for commemorating the extraordinary events that took place and that serve to further the glory of [both of] Your Majesties' names. And now, having finally created it, [a badge] made of gold and with a sash denoting the third, ordinary rank [of the Order], as well as two model drawings, the first of which depicts [the badge] that can be worn by no one other than your own person; and the second one, below it, that is to be worn by princesses of the blood, as well as the twelve [noble] ladies described in the regulations of the Order, - all of these, as well as the written statutes of that Order, I now send along with this letter, hoping that all of it will meet the approval of Your Majesties, while also being in accord with the deed itself. If there is something that does not comply with your wishes, do not take it amiss, for it is sent [expressly] for Your Majesty's gracious consideration. As for the stipulation, mentioned in the statutes of the Order, that it is to be awarded to women only, this [point] has been introduced on the basis of the custom of these [foreign] parts, - on the model of the Order of the [Holy Roman] Empress [of the German Nation] (kak tsesareva imeet ordin), which is awarded to no one other than [noble] ladies. But this [stipulation] should in no way prescribe the intentions of Your Majesties. In the end, I give myself over to the gracious protection (vruchaiu sebia $v$ milostivuiu ... protektsiiu) of Your Majesty, [my] most-gracious sovereign tsaritsa.

8 There are several points to be made in connection with Kurakin's letter to Catherine. Firstly, and in typical early modern European fashion, Kurakin's letter presented the Order of St. Catherine as a "revival," that is, as a demonstration of continuity with the military religious orders founded during the Crusades. ${ }^{26}$ In the case of this particular lay monarchical order of knighthood, the model was unquestionably the semi-legendary crusading Order of the Knights of St. Catherine of Mount Sinai. ${ }^{27}$ 
Figure 1. Knight of St. Catherine [of Mt. Sinai]. Buonanni Filippo, 1638-1725. Catalogo degli ordini equestri, e militari: esposto in imagini, e con breve racconto, offerto alla santita di n.s. Clemente XI

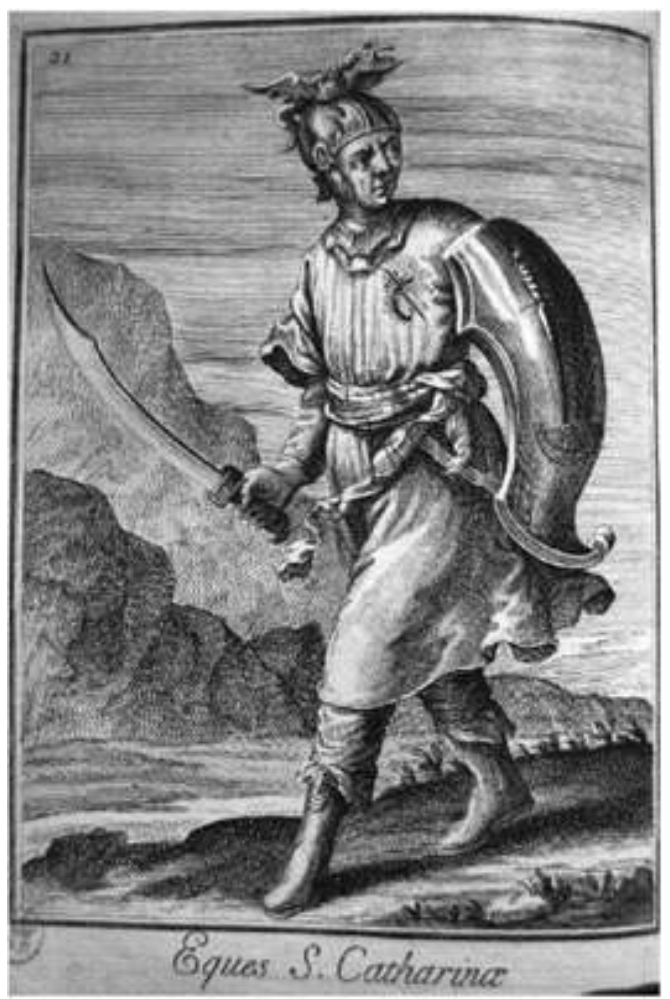

(In Roma: Nella stamperia di Georgio Placco, CDCCXI [i.e. 1711]), Plate XXI [21]: Eques S. Catherinae/ Cavaliere di S. Caterina. Courtesy of David M. Rubenstein Rare Book \& Manuscript Library, Duke University

According to the story repeated by both Protestant and Catholic writers on the subject, ${ }^{28}$ in 1063 A.D. an order of knights had been instituted "under the Patronage of St. Catherine, whose Body was there deposited in the Church of the Monastery erected and dedicated to her Name":

Their first Institution was to guard the said Sepulchre, to secure Travellers, defend the Grecian Pilgrims, and to relieve them with Hospitality. Their Habit was White, and they lived under the Rule of St. Basil the Great, vowing conjugal Chastity, and Obedience to the Abbot of this Monastery, who was their Superior. But when the Turks obtained these Countries, these Knights were ill treated and driven away, and the Order almost abolished; nevertheless some shadow remains for such as travel to visit the Holy Sepulchre at Jerusalem, do now and then pass to this Monastery at Mount Sinai, where in imitation of the Padre Guardian of Jerusalem, the principal Monk in this Convent makes them Knights of St. Catherine over her Tomb, with the like Questions and Formulary as used at the Holy Sepulchre. These Knights now wear upon the left side of their White Habit the Cross of Jerusalem, and Instrument of St. Catherine's Martyrdom; but according to others, the middle of the Wheel is pierced with a Sword. ${ }^{29}$

Others writers disputed the existence of even such vestigial traces. For example, Adriaan Schoonebeek (1657-1705), ${ }^{30}$ "one of the chief agents <...> of Peter's revolution in Russian image-making," ${ }_{11}$ who authored and illustrated the first official publication on knighthood in the Russian language, ${ }^{32}$ asserted that the Order of the Knights of St. Catherine of Mt. Sinai "was completely destroyed during retreat from the Holy Land, which Christian princes were forced to undertake under the pressure of Turkish forces." 
Nor was it ever "formally instituted by one of the Popes," ${ }^{33}$ an eventuality that (if true) would have made the Order of St. Catherine an attractive candidate for revival by any Christian sovereign eager to have his or her own order of knighthood. ${ }^{34}$ Whatever the case may be, neither Schoonebeek nor any other contemporary writer would have found Kurakin's assertion about the "revival" of an old "European" order completely spurious, especially in the context of the "wave of foundations" that followed King James II's decision to "revive" the Scottish Order of the Thistle (also known as the Order of St. Andrew). ${ }^{35}$ As Boulton notes, "In the twenty-two years between 1693, when Louis XIV of France created a third order for his kingdom, and 1715, when the Marquis of Baden founded an order for his principality, no fewer than eleven neo-monarchical orders were either established or endowed with statutes for the first time by European princes especially those who for one reason or another had not inherited such an order from their predecessors on the throne." ${ }^{36}$ Tsar Peter Alekseevich, founder of the Order of St. Andrew the First Called, the first Russian monarchical order of knighthood, was among them. ${ }^{37}$ And so was his wife, who was formally responsible for "reviving" the Order of St. Catherine. But whereas Peter never succeeded in completing a draft of the statutes of his Order ${ }^{38}$ Catherine managed to publish the statutes of her's as early as October 1713.

11 Unlike its ostensible medieval model, the Russian order of St. Catherine was to be composed exclusively of women and devoted to such non-martial pursuits as regularly praying for the health of the tsar and occasionally ransoming a prisoner from the Turks. Although contemporaries knew of the existence of many female orders, ${ }^{39}$ and even some female orders of ransom, ${ }^{40}$ there had never been an exclusively female order devoted to St. Catherine. Indeed, there was no exact parallel to the new Russian monarchical order: it was clearly made up to suit the occasion and fulfill the wishes of its patron. The fact that there was no exact prototype for this "revived" order may explain, at least in part, why the process of putting it together ("coming up with the idea $\langle. .$.$\rangle , designing what it$ would look like, composing its motto, as well formulating its regulations") required as much time and effort as it did. Furthermore, the fact that Kurakin felt the need explain why this order was reserved solely for women suggests that this bit of invention may not have been included in the original commission, and hence, was something added on his own initiative. Fearing that this bold attempt to "divine" the tsaritsa's will might generate surprise and dismay, Kurakin explained that the Order of St. Catherine had, in fact, been modeled on the "Order of the Holy Roman Empress, which is awarded to no one other than [noble] ladies." ${ }^{41}$ This was more than just a flattering, rhetorical move intended to equate the low-born, foreign wife of Peter the Great with Habsburg royalty. As we will see, although Kurakin does not mention the name of the Imperial order that he had in mind, he was undoubtedly referring to one of the two female orders of knighthood instituted in the second half of the seventeenth century by Empress Eleonora Gonzaga the Younger (1630-1686), the third wife of Emperor Ferdinand III (1608-1657, r.1637-1657).

12 The first order of knighthood founded by the widowed Habsburg empress was the socalled Order of the Slaves of Virtue (Ger. Der Orden der Sklavinnen der Tugend, 1662), ${ }^{42}$ a non-denominational assemblage of "virtuous" court ladies, primarily from the Italianate regions of the Holy Roman Empire, who were hand-picked for membership and led by Empress Eleonora herself. ${ }^{43}$ This order of merit rewarded emotional self-control, polite conversation, decorous conduct, and personal loyalty to the Empress, who used it to cultivate the moral and spiritual qualities (Tugendhaftigkeit) and expand the social skills 
of the noblewomen on her staff. ${ }^{44}$ The second order instituted by Empress Eleonora, the Order of the Starry Cross (Lat. Ordo Stellatae crucis; Ger. Sternkreuzorden), was not only much larger and more German, but also much more typical of the intense Baroque religiosity cultivated by members of the late-seventeenth and early eighteenth-century Habsburgs. ${ }^{45}$ The Sternkreuzorden was instituted in 1668 in order to commemorate a "miraculous" event: a fire in the imperial residence in Vienna that left a cross curiously intact. The "purpose of this order was to promote a special devotion to the cross of the redeemer," and its members' duties included "partaking of the sacrament often, reading daily in a spiritual book, and serving the sick and dispensing alms to the poor." The motto of the order, "Salvation and Glory," harkened back to the idea that an imperial war was a crusade against infidels and heretics. And since in the second half of the seventeenth century the Holy Roman Empire was once again leading the charge against the Ottomans, this order served as a timely and politically-opportune reminder of the meaning of the "passion of Christ as a victorious crusade." ${ }^{46}$ The fact that Emperor Leopold I (1640-1705, r. 1658-1705) dutifully acknowledged his mother's new order and formally put it under his protection guaranteed that the noble ladies of the Sternkreuzorden were quickly enlisted to serve the interests of Church and State. ${ }^{47}$

Figure 2. Knight of the Female Order of the Cross. Filippo Buonanni, Catalogo degli ordini equestri, e militari : esposto in imagini, e con breve racconto, offerto alla santita di n.s. Clemente XI

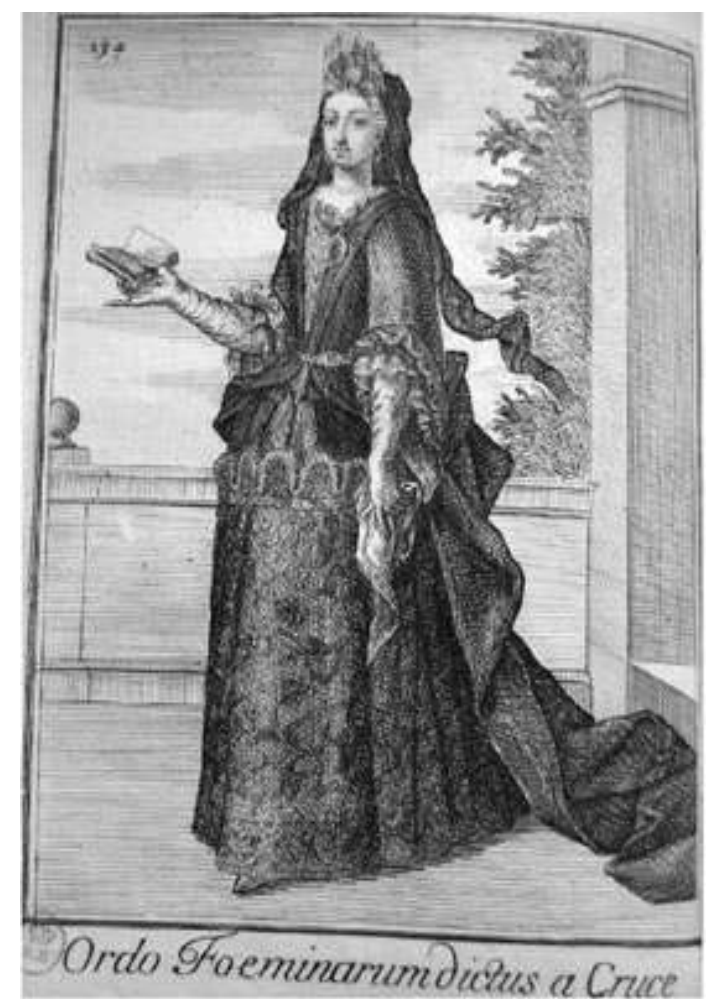

(In Roma: Nella stamperia di Georgio Placco, CDCCXI [i.e. 1711]), Plate CXXXIV [i.e. 134]: Ordo nobelium Foeminarum a Cruce dictus/Ordine di Dame della Crociera Courtesy of David M. Rubenstein Rare Book \& Manuscript Library, Duke University

Until her death in 1686, the Empress-Dowager remained the Grand Mistress (Grossmeisterin) of this elite female order, whose first six members included both widowed and reigning empresses, as well as princesses of the blood..$^{48}$ In 1688, Empress Eleanore Magdalena (1655-1720), wife of Emperor Leopold I and mother of the future 
Emperor Charles VI (1685-1740, r. 1711-1740), reconstituted the Sternkreuzorden and "elevated it to the highest order for female nobility." 49 Russian diplomats, who carefully followed developments in Vienna, were undoubtedly apprised of these events, which took on a special significance in 1711, the year when Tsarevich Aleksei unwillingly waded into the Habsburg marriage pool, having been forced by his father to wed Emperor's Charles VI's sister-in-law, Charlotte Christine of Braunschweig-Wolfenbüttel (1694-1715), ${ }^{50}$ whose older sister, Maria Elisabeth Christine (1691-1750), was not only the new Empress, but also the fourth Lady Knight of the Sternkreuzorden. ${ }^{51}$ Kurakin's letter to Catherine certainly demonstrates that at least some aspects of the history of Imperial female orders were on the mind of Tsarevich Aleksei's uncle, who had taken an active part in the diplomatic negotiations involved in sealing the new matrimonial alliance, ${ }^{52}$ and who was himself a prominent, if "malcontent" participant in the wedding banquet that followed the actual marriage ceremony. ${ }^{53}$

Finally, and perhaps most interestingly, Kurakin's letter to Catherine suggests that although the project ultimately had to satisfy the "intentions" of both of their Imperial Majesties, the badge, the two drawings, and the statutes of the Order of St. Catherine were clearly meant to be presented for the consideration and amendment of the Tsaritsa alone.$^{54}$ Kurakin's word-choice leads us to believe that Catherine, rather than Peter himself, was the first and primary audience for Kurakin's missive, and that it was Catherine, not Peter, whose favor the ambassador explicitly sought. Whether this also meant that the initiative for the creation of a knightly order named after St. Catherine had come from the Tsaritsa herself is more difficult to ascertain, however. This suggestion seems to be supported by the wording of Catherine's letter, which she dictated and sent on 30 September 1713, immediately upon receipt of the package containing the statutes and badge of the new Order:

Noble Mr. Ambassador.

We have received your letter, together with the Order that was sent along with it, for which we thank you very much. The Order was made quite nicely in accordance with our wishes (ves'ma izriadno sochinenen po zhelaniiu nashemu). And since you have sent us a white sash [the original color of the sash associated with the Order of St. Catherine, which would soon be replaced with a red sash - eds.], ${ }^{55}$ we will attempt to make sure that you receive a blue one [that is, the sash of the Order of St. Andrew - eds.], something about which we have already asked His Majesty and which he has deigned to promise [to make happen]. And we hope that this [promise] will actually be fulfilled [in order to compensate you] for your efforts in the name of the [common] weal (za vashi trudy $\mathrm{k}$ pol'ze) of the Russian realm (Rossiiskago gosudarstva). <...> As ever favorably disposed towards you (Prebyvaem vam $v$ milosti sklonnaia), Ekaterina, from Sankt-Petersburkh, on the 30th day of September $1713 . .^{56}$

Although the tsaritsa's secretary signed off using her Christian name, Kurakin would undoubtedly have noted that throughout the letter Catherine had invoked the Russian version of the majestic plural (Lat. pluralis maiestatis), that is, she adopted the royal or plural pronoun, referring to herself using a grammatical number other than the singular in order to emphasize the excellence, power, and dignity of her royal person. She was also very explicit about the fact that the order was made "according to our wishes," and that in (admirably) fulfilling his task, Kurakin was carrying out her expressed orders. In other words, the letter emphasized the unequal relationship between the commonertsaritsa and her noble-born subject, a relationship in which Catherine acted the parts of both patron and intercessor. Not only was she responsible for commissioning something 
from her subordinate, but as the acknowledged royal consort she was also the individual in the best possible position to make sure that he would actually be rewarded for his efforts. Indeed, the letter projected a sense that Catherine was not only empowered to make a request of her royal husband, but also quite confident that her request will eventually be granted. ${ }^{57}$

Kurakin, who still smarted from the humiliation of being deliberately passed over for promotion after the battle of Poltava ${ }^{58}$ and who actively sought to acquire a knighthood in recognition for his efforts as a diplomat, ${ }^{59}$ was delighted by Catherine's enthusiastic response. "From your <...> decree [sic] (ukaza vashego), dated 30 September," Kurakin wrote,

I gathered that the newly-created and recently-mailed Order was respectfully delivered on my behalf to Your Majesty and that in its form (slozheniem) it conforms to the will of Your Majesty (skhoden s voleiu vashego velichestva). Having understood this, I report with great joy, that I will gladly do whatsoever I will be ordered by Your Majesties' decree (po ukazom vashiskh velichestv), and will perform my service assiduously and faithfully. Initially I was senseless with joy at the thought of all the gracious attestations that were made on my behalf, as described in Your Majesty's [previous] writ, especially since what was promised me was to some extent put into action. I will accept the gracious announcement reflecting [both of] Your Majesties' favor towards me as if I have already received and now possess the [promised honors], even if it will take a long time to carry out this resolution, or even if in time it does not take place at all. ${ }^{60}$

17 As it happened, Kurakin's caution was well-placed. For not only did he have to wait four years before Peter deigned to award him the Russian cordon blue, which he finally did in $1717 .{ }^{61}$ But Catherine herself had to wait over a year, until 24 November 1714, before Peter "publicly" (publichno) awarded her the "newly-created badge of the Order of the Holy Martyr Catherine" (novouchinennuiu kavaleriiu ordena Sviatyia Velikomuchenitsy Ekateriny);62 and another eleven years after that before actually assuming the role of Grand Mistress, with the right to hand out knighthoods as she pleased.

In his attempt to present himself as a "faithful" and "assiduous" royal servitor, Kurakin made a point of stressing the extraordinary effort required to carry out Catherine's "decree" about "instituting an Order." However, the Prince appears to have somewhat exaggerated his own contribution, especially regarding the composition of the statutes. For contrary to Kurakin's assertion, the delay was due not so much to the difficulty of "coming up with the idea for it" as of finding the right person who could do this job for him. Just as he had done only two years earlier, in connection with his first commission from the Tsaritsa ${ }^{63}$ Kurakin successfully assembled a team of foreign specialists to carry out Catherine's request. Thus, on 15 August, 1713, a certain Balius was paid twenty gold pieces (chervonnyi) for designing the star and motto of the projected new Order, while a goldsmith received fifty guilders for actually making the badge; another master got eight guilders for engraving the motto, and a seamstress got seven guilders for making the white sash with appropriate embroidery. On that same day, according to Kurakin's account book, the Russian embassy paid the hefty sum of fifty Joachimsthalers to a certain "Mr. Dumand for composing the regulations of the Order of Deliverance" (Dano gdnu Dumandu za kompozitsiu reguly ordina Svobozhdeniia). ${ }^{64}$

Judging from Kurakin's business correspondence, this was apparently the very same individual ("Mr. Du<...>) from whom, on July 20/31, the embassy had received a clean 
version of the "Project d'un ordre de Chevalerie qui pouvoit etre institute en faveur des Dames a la Cour de sa maj..$^{\text {te }}$ Czarienne." Just a month earlier, on 27 June 1713, the Russian ambassador had asked for official permission to hire a "skilled advocate" called "Dumon" to help him compose diplomatic documents ("written proposals, acts, protestations, memorandums et cetera"). According to Kurakin, this "Dumon" had been previously employed in just such a capacity by Graf Philip Ludwig von Sinzendorf (1671-1742), the Imperial representative at the Utrecht peace congress, but with the end of negotiations was presently without a job. ${ }^{65}$ While awaiting the official response from the Russian foreign office, Kurakin contracted the "advocate Dumon" on a free-lance basis, and the permission to hire the new foreign specialist at the requested salary of 1 000 Joachimsthallers per year arrived from St. Petersburg on August 17, two days after he had already been compensated for his effort in composing the "regulations" of Russia's first female order of chivalry. ${ }^{66}$

21 Although the Russian transcription of the French surname makes it difficult to say for sure, the "advocate" in question appears to have been none other than Sieur Jean Du Mont (or Dumont, as he is more commonly known), Baron de Carlscroon (1667-1727), "a prolific writer and tireless publicist for the Holy Roman Empire." ${ }^{\prime 7}$ Today, Du Mont is best remembered for his Corps universel diplomatique du droit des gens, a multivolume compilation of international treaties.$^{68}$ However, in 1713 , he was actively publishing anti-British pamphlets - a stance that fit very well with both Vienna's resentment of the results of the congress of Utrecht and Peter's resentment of London's attempts to force the tsar to make peace with Sweden on terms he considered unfavorable. The Frenchman's links with the Habsburg minister, which Kurakin mentioned only in passing, actually went back a dozen years and lasted for Du Mont's entire career as a political émigré. Sinzendorf's patronage brought Du Mont not only a baronial title, but also an appointment as historiographer to Emperor Charles VI. This obviously put him in a position to be well-informed about the Habsburg system of honors, which as we saw above, included the female order of chivalry that served as the model for the Order of St. Catherine. We do not know how long his full-time work for Kurakin lasted, but judging by the fact that Du Mont's Corps universel included, among other things, a Latin translation of the heavily-revised draft of the 1711 Pruth armistice, ${ }^{69}$ Kurakin apparently remained on good terms with the Frenchman long after his employment formally ended. ${ }^{70}$ But regardless of the length of their cooperation, one thing is clear: the original draft of the statutes of the Order of St. Catherine turns out to have been written neither by Peter, nor even by Kurakin himself, but rather by Du Mont.

Although Du Mont was the author of the proposal to institute a female order of chivalry at the Russian court, the contribution made by Kurakin and his staff is still highly significant for our understanding of the projects' place in contemporary court politics. An analysis of their contribution, and particularly of the changes that they introduced in the translated text, provides additional insight into the process that resulted in the creation of the Order of St. Catherine and the roles and agendas of its individual contributors. As can be seen from the document published in the second appendix to this article, Kurakin did not change the structure of the text, the symbolism and procedures of the Order, or the design of its insignia: with the single exception of the Order's motto, to which we will return below, all these aspects of the French Project made it to the published version of the Statute without undergoing any changes whatsoever. In fact, for the most part, Kurakin's editing was largely stylistic. For example, Kurakin amended Du Mont's description of the Pruth battle by replacing the adjective "ferocious" (svirepogo) 
with "bloody" (krovavogo), a substitution that was much more in keeping with contemporary allusions to the Christ-like suffering of the Russian tsar and his realm that began to appear in Peter's correspondence, as well as in religious icons, in the wake of the 1711 defeat. $^{71}$ The polyglot prince also helped to find better Russian terms for certain foreign phenomena, for example, by changing "kavalernykh" ladies into "kavalerstvennykh." And of course, true to his aristocratic political convictions and Polonophile tastes, Kurakin did not miss an opportunity to change the translation of the original's phrase "toutes nobles d'extraction" from "dvorianskogo" to "shliakhetnogo urozhdenia," in effect, replacing the Muscovite term for a member of the provincial, nonhereditary service class (dvorianin) with the Polish word for the noble estate (szlachta). ${ }^{72}$

Some of the changes introduced by Kurakin, however, have a much more explicit political meaning. For example, Kurakin and his assistants found themselves compelled to rewrite over and over again the passage explaining the reasons for the Pruth campaign. This attention to what, in his letter to Catherine, Kurakin called "the deed itself" derived not merely from the fact that the miraculous moment that supposedly sparked the "restoration" of the Order of St. Catherine took place during this campaign. This section also demanded extra attention because in the summer of 1713, peace negations at Istanbul were still dragging on and the Russian government seriously feared that the hostilities might resume at any time. One of the key points of contention was the question of Russia's fulfillment of the terms of the armistice signed at the Pruth, especially the point about Russia's non-interference in Polish affairs. This situation was complicated by the fact that one of the possible routes that King Charles XII and his troops were to take on the way back to Sweden lay through Poland. Consequently, diplomatic tact may explain why Poland, which is mentioned by Du Mont, was later struck from the final version of the Statutes..$^{73}$ Similarly, as one would expect from a diplomat long-accustomed to negotiating over how his monarch would be addressed, Kurakin made sure to indicate those places in the text where an informal reference to the "Tsar" should be replaced by a proper title. Kurakin was also very careful in how he referred to the Tsar's official consort. Thus, when his assistant first translated the French "Grand Maîtresse" as "pervenstvuiushchaia persona," Kurakin provided the following gloss in the margins: "or grand maitresse in French" (ili po-frantsuzski grand metresu). On second thought, the Prince realized that this way of rendering the title of the Order's Grand Mistress sounded highly dubious, because by that time the term metresa had been already well-established among the Europeanized Russian elite with a very different meaning. When applied to Catherine, who until recently had been Peter's metresa in this quite unflattering sense, the phrase grand metresa must have sounded especially ironic. Kurakin was evidently so bothered by these connotations that in the version eventually dispatched to Catherine he switched from French to German, explaining that "gospozha ordinu" is the same as "Gross Meisterin des Ordens."74

Especially important and revealing, however, are two further changes made by Kurakin. First of all, it is striking that the Prince crossed out from the Russian text all references to Tsarevich Aleksei and his German bride, who had permanently relocated to Russia only in the spring of $1713 .^{75}$ The French Project refers to the tsarevich (without calling him by name) on a number of occasions, and the translators render these word-for-word. For example, initially in paragraph five the Ladies of the Order were called upon to pray not only for the tsar, but also for the "well-being, health, and longevity of the Sovereign Tsarevich, and of His Consort, and of the Princes and Princesses of the Tsarist Family." Kurakin, however, replaced this phrase with a reference only to the "well-being, health, 
and longevity of His [i.e., the Emperor's - eds.] heirs and of the entire Imperial Family." He did the same thing in paragraphs eight and thirteen, where the original references to the "Princess-Consort of the Sovereign Tsarevich" (printsessa supruga gosudaria tsarevicha) as the one who automatically receives the Grand Cross of the Order and stands in for the reigning empress in case of the latter's absence, are mercilessly crossed out and replaced with more vague references to the imperial princesses in general. By introducing these changes, Kurakin in effect guaranteed that the pedigreed, blue-blooded bride of the presumed heir-apparent would not be allowed to assume precedence over any of the royal ladies in the Romanov household unless and until she actually became the reigning empress - a point that would have been particularly important for the low-born tsaritsa and her "illegitimate" (because born out of wedlock) daughters.

We must remember here that in the summer of 1713 , when Kurakin was editing the Statutes of the Order of St. Catherine, the fall and disinheritance of Tsarevich Aleksei had not been preordained. In fact, at the end of 1713 Aleksei was entrusted by his father with probably the most important practical task yet: he was sent to ensure the speedy delivery of timber for Peter's crash program of building a fleet of small galleys on the Baltic - an enterprise which together with the program of purchasing warships abroad, supervised by Kurakin himself, was the key to Peter's hopes of defeating Charles XII 's navy, the most important of the remaining bulwarks of Swedish power. ${ }^{76}$ Yet, as the revisions introduced by Kurakin and his staff suggest, already in 1713 any references to Tsarevich Aleksei and his wife were perceived as a political mistake. It is not difficult to conclude that either Kurakin knew something about Peter's views regarding Aleksei's future that we do not know - or, more likely, that the Prince's efforts to expunge any mention of the recent newly-weds from the Statutes of the Order reflected his understanding about the hopes or, perhaps, even plans that Catherine and her supporters may have entertained regarding the place of her own children in the line of royal succession. The rules enshrined in the statutes of Catherine's new female order thus not only attempted to regulate the order of precedence among the women of the Russian royal household, but also to defuse some of the political tensions associated with the integration of the tsaritsa's new daughter-in-law (nevestka) into Petersburg court society.

No less suggestive is another editorial decision made by Kurakin, this time concerning the proposed motto of the Order. The phrase "For Love and Fatherland" (Za liubov' $i$ otechestvo), traditionally associated with the Order of St. Catherine, does not appear in the original text of the statute written by Du Mont and, in fact, does not even fit his concept of the order. The French project is consistently built around the theme of divine intervention and its visual symbol, the divine light. Du Mont begins his preamble with a reference to numerous cases when Providence miraculously intervened on behalf of the young tsar, protecting or "delivering" him from his domestic and foreign enemies hence the original name of the Order. The ultimate survival of the tsar's army at the Pruth campaign served as yet another, and perhaps most wonderful example of such providential deliverance. The author of the preamble emphasizes the hopelessness of Peter's situation at the Pruth: surrounded and outnumbered many times over, he could not hope to save himself and his army, all his "unconquerable bravery, prudence, and heroic firmness" notwithstanding. The peace comes, therefore, as a miracle pure and 
simple, as a divine light descending from Heaven. There is no room in this picture for Catherine and her legendary efforts to bribe the grand vizier, an apocryphal story that is not even hinted at in the Statutes. Instead, the tsaritsa's role is emphatically that of a dutiful wife of Russia's divinely-anointed warrior Tsar, and the Order celebrates not her resourcefulness, but her eagerness to serve as a witness to this moment of epiphany.

Du Mont's insistent use of the metaphor of divine light helps to explain why his draft of the Statutes of Russia's first female order of chivalry had only one passing reference to St. Catherine of Alexandria, and why the original design of the star of the Order included no images of the martyr or her symbolic attributes. Instead, the projected star of the Order was to bear two crosses. The larger one was meant to symbolize God's creation of Light (Genesis 1:3). Upon this cross there was to be superimposed another, smaller one, surrounded by a halo embodying the Light of Nations described by the Prophet Isaiah ("I have given thee to be the Light of the Gentiles, that thou mayst be my salvation even to the fartherst part of the earth," Isaiah 49:6). The motto of the Order, again suggested by $\mathrm{Du}$ Mont, was fully consistent with this concept. It read "Ex Tenebris Lux" ("Out of Darkness, Light") - a paraphrase of another Biblical quote, this time from St. Paul's second epistle to the Corintheans (2 Cor. 49:6), which in Latin read "quoniam Deus qui dixit de tenebris Lucem" ("for God has commanded the light to shine out of darkness"). This was a common trope of Protestant spirituality, especially when speaking about instances of contemporary (as distinct from biblical or historical) divine revelation, which may explain why the French Huguenot used it to describe the epiphany at the Pruth. ${ }^{77}$ This motto, however, was clearly not to Kurakin's liking: he personally crossed it out and wrote on the margins another one, the famous "For Love and Fatherland," together with its Latinate version "Pro Amore et Patria." As can be seen from the document in Appendix II, Kurakin briefly toyed with the idea of specifying not just any "Amore," but "Amore Conjugal" (Lat. amor coniugalis, i.e. marital love), in affirmation of Catherine's relatively-recent status as official consort and Du Mont's depiction of her as the dutiful wife. However, in the end Kurakin decided to return to the shorter version (perhaps, because he remembered that Catherine's young daughters, as well as other unmarried Russian royal women, would also presumably qualify for induction into the Order). It is not hard to see that this new motto had absolutely nothing in common with the rest of the document and with the overall symbolism of the Order as envisioned by the author of the Statutes: neither love nor fatherland (nor even the more familiar notion of "love of fatherland," amor patriae, as in the popular heraldic devise, Pro amore patriae) was ever mentioned in Du Mont's text. In fact, this was the one and only time when the Prince's editing went beyond correcting stylistic and political mistakes: Kurakin's motto went against the very logic of Du Mont's project. ${ }^{78}$

Kurakin's decision to replace Du Mont's proposed motto did, nevertheless, have a logic all its own. And that logic was intimately tied to Kurakin's desire to please the tsaritsa by tactfully recalling her role in another, earlier project to create a Catherinian-themed order of chivalry. Although the star of this projected knightly order bore the same motto as its better-known counterpart, and appears to have been intended for none other than Prince Aleksander Danilovich Menshikov (1673-1729), Peter's long-time court favorite, it is never mentioned in histories of Russian imperial honors, and seems never to have been officially recognized, approved, or bestowed by the tsar. ${ }^{79}$ Indeed, the only reference to this order comes from a letter written in Kobeliaki, a village halfway between Poltava and Perevolchna, and dated 9 July 1709, in which Menshikov gratefully 
acknowledged the receipt of his wife's "letter, as well as the present that was sent along with it," namely, a drawing of "the star of an order of chivalry" (pis'mo vashe i poslannoi prezent kavaleriiu). ${ }^{80}$ Judging by the sketches preserved among the Menshikov papers, and reproduced here for the first time (Figure 3), the motto of this one-of-a-kind order was indeed the very same one that Kurakin later chose for the devise of the Order of Deliverance.

Figure 3. Catherinian-themed order of chivalry, c. 1709. RGADA, f. 198 (Menshikov), op. 1, d. 1170 (Letters of A.D. Menshikov to Daria Menshikova), I. 134. Courtesy of the Russian State Archive of Ancient Documents, Moscow (GARF)

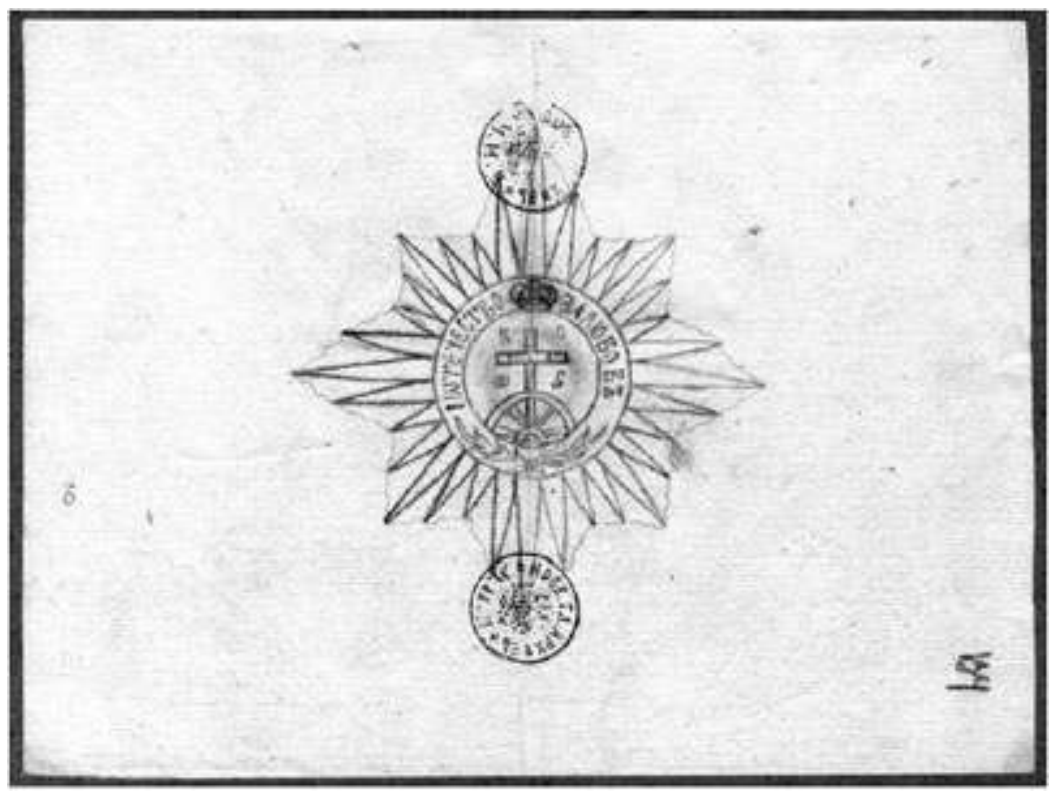

Even more importantly, at the center of the star of the earlier order was an image of a cross mounted on a wheel - the traditional attribute of St. Catherine of Alexandria. ${ }^{81}$

Although it is still unclear who commissioned this order, or what was the ultimate purpose for which it was intended ${ }^{82}$ it is quite likely that the initiative came from the household of Menshkov himself. It is well known, of course, that Menshikov was the earliest, and most enthusiastic supporter of Catherine, and that the tsaritsa always gratefully returned the favor. What is far less known is how extraordinarily close the female members of the Menshikov household were to the future tsaritsa, who gave birth to and raised her and Peter's children in their company. ${ }^{83}$ Both Daria Menshikova (née Arsen'eva), and her unmarried sister, Varvara, had long been members of the tsar's extended family, having started their careers at court as ladies-in-waiting to Peter's sister, Tsarevna Natal'ia Alekseevna. And when Marta (a.k.a. "Katerina Vasilevskaia") first became the tsar's mistress, in 1704, she joined this small coterie of women, who supported each other through their men-folk's long absences and sometimes lived and travelled together in one common household. The women strove to be as close to their men as possible, spending holidays with them, inquiring about their health, and exchanging frequent letters and gifts. In 1708-1709, during the military campaign in Poland and Ukraine, the three women seemed to have spent most of their time traveling together: since at least August 1708 in most of his letters to his wife Menshikov also sent his best regards to "auntie (tiotushka) Ekaterina Alekseevna." Catherine and Varvara were with Daria when she gave birth to Luke-Peter, the Menshikovs' first-born son, in 
February 1709. And from mid-May 1709 until after the battle of Poltava, all three of them stayed in Kharkov..$^{84}$ Consequently, whatever gift was being prepared for Menshikov in the summer of 1709, Catherine was more than likely to have known all about it, if not instigated it.

We do not know what either Peter or Catherine made of this attempt by her personal companions and political supporters to create an order of chivalry that was so obviously connected to her patron saint. One the one hand, it seems clear that this order was designed to link loyal and supportive wives to their victorious husbands, thereby giving women a role beyond that of simply pious mothers and keepers of the household. Indeed, despite Peter's assertion to the contrary, the order "For Love and Fatherland" suggested that women's labor entailed much more than merely praying for the health and welfare of their men..$^{85}$ On the other hand, this scenario seems like an obvious attempt to promote the "political cult" of St. Catherine and Catherine personally. If that is indeed the case, then one would assume that the tsar would be central to this endeavor. And yet the role of Peter remains obscure. We know that it was precisely at the very end of May that Peter stayed in Kharkov for a few days on his way to Poltava. ${ }^{86} \mathrm{He}$ must have been aware of the project to institute a Catherinian-themed order, and he must have, at the very least, not objected to it being created and bestowed upon Menshikov. But at this point, we do not know whether Peter actively supported it, or on the contrary, saw this as just another one of Menshikov's ploys, designed to put additional pressure on the tsar to make him keep his word (parol') and marry Catherine.$^{87}$ If it is true, as Mikhail Dolbilov has suggested, that royal advisors typically try to guess the monarch's intention and then formulate for him what they think he wants to say, then the 1709 incident may have been less about putting pressure on Peter (who already promised to marry Catherine and raise her profile) than an attempt to formulate one, concrete way of carrying out his wishes.

What we can be reasonably assured of is that Kurakin's decision in 1713 to add the phrase "Pro Amore et Patria" as the motto of a Catherinian-themed, female order of chivalry demonstrated his familiarity with this earlier episode, or at least with one of its chief protagonists. In the winter of 1708-1709, Kurakin certainly enjoyed a very close relationship with Menshikov, the original recipient of the proto-Catherinian order and the most likely source of information about its motto. By his own testimony, Kurakin had

led the Semenovskii and Astrakhan regiments that accompanied Prince Menshikov [all the way] to Akhtyrka, where we camped that whole winter, up until the very time that we chanced to join up with the whole army near Poltava, in the spring; I conducted myself well (byl $v$ povedenii dobrom) and was in fine form ( $v$ mere izriadnoi) with the Illustrious Prince (ot ego svetlosti kniazheskoi).

$\mathrm{He}$ and Menshikov often dined together during their stay at winter quarters in Akhtyrka and it was at one of these soirees that the tsar gave Kurakin the dressing down that cost him his promotion. ${ }^{88}$ We know that Kurakin, as a senior officer of the Semenovskii Guards, saw action at Poltava. And since the Guards regiments that he commanded formed part of Menshikov's "flying corps," which was sent to chase the fleeing enemy, he was likely to have been present at Kobyliaki. Consequently he was in a position to witness the arrival of Daria Menshikova's gift to her husband, just as he had earlier witnessed the arrival of the news about the birth of Menshikov's first-born son. ${ }^{89}$ 

of the Order of St Catherine and of Catherine's role at Peter's court. We are not ready to claim at this point that Peter was completely uninvolved in the creation of the Order of St Catherine: the archives still hold too many insufficiently-studied documents. Yet, some key facts, as they emerge so far, are worth emphasizing. We know that Prince Kurakin maintained an extensive correspondence with Peter in 1712-1714 covering a variety of subjects, from peace negotiations to the tsar's requests for purchases of saplings of trees, construction materials, foreign delicacies, and expensive works of art. Yet, nowhere in this correspondence, both published and unpublished, were we able to find any mention of the Order of St. Catherine. We do not have any evidence of Peter's direct involvement in either the creation of the proto-order of St Catherine in 1709 or the actual Order of Deliverance in 1713. Peter did not edit the Statutes of the Order, which were published exactly as Du Mont and Kurakin had written them, and he bestowed the star of St Catherine upon his consort almost a year after this document rolled off the presses of the St. Petersburg Typography. Despite Catherine's promises, Kurakin was not awarded by Peter for his efforts, and, contrary to the terms of the statutes, no one except Catherine ever received the order during his reign. In fact, for as long as Peter was alive, Catherine remained the sole member of an Order that, for all intents and purposes, existed only on paper. model for the first Russian female order, Peter never formally took the newly-instituted Order of St. Catherine under his Imperial protection. ${ }^{90}$ Instead, he appears to have treated the star of his wife's new order more like a commemorative medal (akin the ones struck in honor of particularly noteworthy individuals ${ }^{91}$ or specific special occasions), ${ }^{92}$ than as a visible sign of her induction into a chivalrous organization. The knightly badge (kavaleriia) that Peter publicly pinned on Catherine in November 1714 was intended to recall the miraculous act of "deliverance that took place during the battle on the Pruth, at which Her Majesty deigned to attend her own royal self" ( $v$ pamiat' izbavleniia sluchivshagosia pri Prutskoi batalii, gde Ikh Velichestva vysokoiu Svoeiu osoboiu prisutstvovat' izvolili), ${ }^{93}$ not to celebrate any specific meritorious action on her part. ${ }^{94}$ It is only later, and partly in response to the persistent rumors to the effect that the real reason why Peter and his army escaped Ottoman encirclement was Catherine's supposed willingness to collect all the jewelry on hand so as to bribe the Grand Vizier ${ }^{95}$ - that Peter and his panegyrists re-interpreted the tsaritsa's mere presence at the Pruth as a sign of the kind of "masculine bravery" (muzhestvo) expected from a woman who was a worthy partner to the Great All-Russian Emperor. ${ }^{96}$

37 Catherine, on the other hand, personally supervised Kurakin's work on the Order. And as soon as she got an opportunity - i.e. after Peter's death - Catherine began wielding her titular authority as Grand Mistress and bestowing the order upon members of her entourage. ${ }^{97}$ The widowed tsaritsa awarded the Order first to her own daughters (Anna and Elizabeth, both in 1725); and then to the other Russian royal ladies (Anna, Ekaterina, and Praskov'ia, the three daughters of Tsar Ivan Alekseevich, in 1726). The first non-royal to receive the Order was her personal confidant (Daria Menshikova), who was inducted in 1726, on the same day as the sole female offspring of Tsarevich Aleksei (Natal'ia). ${ }^{98}$ As we saw, Daria appears to have been intimately involved in an earlier attempt to create a proto-Catherinian order, a move that nicely dovetailed with her husband's efforts circa 1708-1711 to make Peter "keep his word" by officially marrying Catherine and later to 
promote her image as Russia's sovereign tsaritsa. In fact, already in 1713 Catherine and her entourage seem to have harbored hopes and, perhaps, even actively schemed to remove Aleksei from the line of succession and replace him by her own progeny. Certainly Kurakin's decision to remove all references to the legitimate heir to the throne from a document that Catherine intended to publish was nothing if not a political declaration of extreme boldness. From this brief synopsis of the facts, it seems reasonable to conclude that far from being a passive participant of Peter's dynastic scenario, Catherine - supported by her immediate entourage - was already in 1709-1713 an active political actor, much more active than previously supposed. It is noteworthy also, that while Kurakin and, apparently, Menshikov played key roles in this story, Catherine appears here not as a hapless figurehead in their hands, but as a politician in her own right, someone who was able to maintain a sustained interest in the Order and to use this project for self-promotion and for building her own client network.

These conclusions also have wider implications for our understanding of Peter's reign that go beyond the story of the Order of St Catherine. In this particular case we have a project which has been traditionally assumed to be driven by Peter, even though historians did not have direct evidence of the tsar's involvement - simply because, it seems, everything taking place during Peter's reign is automatically taken to be emanating from him. Yet, as our study indicates, this appears not always to have been the case. If so, there may be some other "Petrine" reforms and projects, the history of which could be written without Peter as the main protagonist. And even in those cases where the tsar's personal role is clear and present, we might need to be much more attuned to the existence of other voices, interests, and intellectual agendas in ostensibly Petrine documents. The very fact that the woman who served as "Galatea" to Peter's "Pygmalion"99 was the moving force behind the inauguration of the Order of St. Catherine only underlines the need for a more nuanced and, among other things, more explicitly gendered, political history of Peter's reign, one that takes full advantage of recent developments in the study of early modern court in general, and of queenship in particular. ${ }^{100}$

Finally, this article illustrates another point, namely, that such projects, be they driven by the monarch or by other key actors, should be seen within the framework of patronclient networks and, indeed, as vehicles for establishing and maintaining such networks. ${ }^{101}$ The importance of the story of the Order of St. Catherine - why it matters - has to do with more than just the fact that it was actually the first Russian monarchical order to have its own set of statutes. Rather, the story reveals the functioning of a patronage network composed of Catherine, the Menshikovs, and their clients - as well as their combined search for royal favor using chivalric ideas popular at court. By asking Kurakin to draft the statute of Russia's first female order of chivalry Catherine managed to turn him into her client and to set herself up as his patron. Kurakin certainly was not the only member of the Russian elite qualified to carry out this task: there were other Russian diplomats abroad, and there were other officials, both native-and foreign-born, who knew foreign languages and the customs of foreign parts. Consequently, Catherine's decision to recruit Kurakin for this task demonstrates her ability to exploit the Prince's less-than-cordial relationship with the tsar, a relationship that forced him to search for other high-placed patrons, such herself and Menshikov. In turn, the chance to "divine" the tsaritsa's will offered Kurakin not only the opportunity to get back into royal favor, but also, to garner the political support necessary to advance his own ambitious personal 
and professional agenda, which included brining his only son safely out of Petrine Russia, and gaining formal recognition as a leading Russian diplomat. ${ }^{102}$

In fact, this was not the only episode when Kurakin attempted to use his vaunted familiarity with the customs of foreign courts and Catherine's apparent interest in chivalric orders for self-promotion. In 1727, shortly before Catherine's death, he sent Menshikov a letter claiming that on ceremonial occasions the members of the key European orders wore not only the stars, but also special chains. As the ambassador explained, being a loyal servant of the crown, he had commissioned on his own initiative a copper and enamel model of such a chain for the Order of St. Andrew, and now he asked Menshikov to forward the model to Catherine hoping that "this invention would be to Her Majesty's pleasure." 103 Alas, before the empress had time to express her approval of this "invention," she was dead; by the end of the year, Kurakin was dead too, and Menshikov was on his way to exile in Berezov.

\section{Appendix I. [1.236] PROJET D'UN ORDRE DE CHEVALERIE QUI POUVAIT ÊTRE INSTITUTÉ EN FAVEUR DES DAMES À LA COUR DE SA MAJ. ${ }^{T E}$ CZARIENNE*}

À la gloire de Dieu, tout puissant et tout bon Catherine par la grâce de Dieu Czaritse...

À tous ceux qui ces présentes verront salut:

Il n'y a personne qui n'ait quelque connaissance de grandes et précieuses bénédictions qu'il a plu a Dieu de répandre abondamment sur le très-haut, très-excellent et trèspiussant Prince, Pierre Alexioviz par la grâce de Dieu... mon très-honoré seigneur et très cher Époux. Il l'a gardé comme miraculeusement dés son enfance contre [1. 236 ob.] les pernicieux desseins de ses ennemis domestiques, contre les conjurations ouvertes et les rébellions de quelques-uns de ses sujets, et contre les dangers continuels des longues et sanglantes guerres où il s'est trouvé engagé.

J'avais l'honneur de l'accompagner au mois de Juillet 1711 lorsque pour fermer le chemin aux ennemis de la foi, prêts d'entrer en Pologne, il l'avança si généreusement jusques sur les bords de la rivière de Pruth, où il se trouva environné de leur multitude. Il n'y avait nulle proportion entre leurs forces et les nôtres ; les vivres nous avaient été entièrement coupés ; toute la valeur imaginable semblait impuissante à nous secourir. La délivrance ne pouvait venir que de Dieu, elle vint, et après un combat qui dura trois jours, et dans lequel je fus le témoin oculaire du courage invincible de mon [1. 237] Auguste Époux, de la prudence, et de la fermeté héroïque, j'eus la joie inexprimable de voir, comme au temps de la Création, une éclatante lumière de paix, sortir du sein du ces ténèbres. 
À ces causes, désirant de perpétuer à jamais la mémoire de cette délivrance signalée, j’ai résolu d'établir et d'instituer comme de fait j'établis et institue par ces présentes à la gloire de Dieu, et à l'honneur de la Bienheureuse Catherine D'Alexandrie, dont je porte le nom, un ordre de Chevalerie qui sera composé de Dames nobles, honorables et pieuses, mariées et non mariées dans la manière qui suit.

1. Je recommande très humblement cet ordre à la Protection du Czaar Mon Seigneur, le suppliant de la regarder comme une marque de tendre amour et du profond [1 237 ob.] respect que je lui porte, et en cette considération de l'approuver et de le confirmer; afin que sous l'autorité de ses Décrets Impériaux il soit maintenu et perpétué à jamais dans l'Empire de Russie.

2. Le dit Ordre sera nommé L'Ordre de la Délivrance en mémoire de celle qu'il plût à Dieu d'accorder au Czar Monseigneur dans la longue et sanglante bataille de Pruth moi y étant et le voyant ; et en mémoire de toutes les autres délivrances qui avaient précédé celle-là.

3. Il sera composé d'une Grande Maîtresse, d'autant de Dames Grand Croix, qu'il y aura de Princesses du Sang Impérial; de six autres Dames Grand Croix, et des novante quatre Dames Chevalières, toutes nobles d'extraction.

4. Le marque de l'Ordre sera [1.238] une Croix blanche en signe de pureté, dans un champ de pourpre pour montrer que chaque Dame qui le portera, doit plutôt mourir que de manquer à ses vœux.

La Création de la Lumière selon qu'elle nous est décrite au premier chapitre de la Genèse sera dépeinte au milieu de la Croix, et dans le centre une autre petite croix resplendissante, pour signifier la Clarté de l'Evangile qui a été donné pour lumière aux nations afin qu'elle soit en salut jusqu'au bout de la terre, dit la Prophète Isaïe Chap. 49, Vers. 6. Entre les branches de la croix seront placées quatre lettres D.S.F.R., qui sont les primitiales des paroles de Psaume 19 Domine Salvum Fac Regem. Toute Dame Chevalière portera cette Croix sur les habits du côté gauche a l'endroit du cœur, et elle y sera attachée par un ruban blanc sur lequel seront écrites pour devise en lettres d'or ces paroles de la seconde épître de St.Paul aux \{[1. 238 ob.] Corinthiens, Chap. 49, Ver. 6, Ex tenebris lux. La croix de Dames Grand Croix seront plus grandes et d'une autre sorte que celles des Dames Chevalières; la bordure en sera aussi d'un plus grand prix ; et celle de la Grande Maîtresse sera distinguée de toutes les autres par sa grandeur et par sa richesse. Ces trois différentes sortes de Croix sont ici représentées en modèle, afin que la figure, manière et grandeur en soient déterminées et que dans la suite du temps elles ne souffrent point d'altération.

5. Les obligations de toute Dame Grand Croix et toute Dame Chevalière seront, 1. De remercier Dieu tous les jours pour les merveilleuses délivrances et pour les innombrables bénédictions qu'il a jusqu'ici accordé au Czaar Monseigneur ; 2. De prier Dieu pareillement tous les jours pour la conservation de la personne sacrée, pour la prospérité de ses armes et [1.239] de ses affaires, et pour Sa santé et longue vie, comme aussi pour la prospérité, santé et longue vie du Prince Czarien, héritier présomptif de l'Empire, de la Princesse Son Épouse, et de tous les Princes et Princesses de la Famille Royale ; 3 . De réciter tous les dimanches à cette intentionlà, trois fois l'oraison Dominicale, à l'honneur des trois personnes de la Sainte Trinité ; 4. De procurer autant qu'il sera possible la conversion de quelque infidèle à la foi de Notre Seigneur Jésus Christ, en y employant les voies amiables de la 
persuasion, non celles de la menace et de la contrainte ; 5 . Et de retirer un Chrestien de l'esclavage des Turcs en le rachetant de leurs propres deniers.

6. Outre cela toute Dame qui entrera dans l'Ordre, fera vœu solennel d'être fidèle au Czaar, de n'entrer jamais dans aucun [1. 239 ob.] complot contre sa Personne, ni contre son autorité souveraine, ni contre son service, mais au contraire de révéler au plutôt au Czar même ou à la Czaritse Grande Maîtresse de l'Ordre tout ce qu'elle pourrait avoir appris de semblable, sans exception de personnes ou de circonstances. Ces vœux se feront avec serment sur les Saints Evangiles, en présence de la Grande Maîtresse, et d'autant de Dames Grand Croix ou Chevalières qu'il s'en trouvera pour lors à la Cour. On priera aussi le Patriarche d'intervenir et en cas d'empêchement on y appellera du moins quelqu'un des Principaux Ecclésiastiques. Les Dames qui seront absentes pourront faire leur serment par Procureur et celles qui seront en bas âge, en seront dispensées jusqu'à leur seizième année.

7. Je me réserve pour moi seule, et pour les autres Czaritses après moi la dignité de Grande Maîtresse de l'Ordre.

8. J'appelle à la dignité de Dames Grand Croix toutes les Princesses \{1.240\} du Sang Impériale nées ou à naître en quelque temps et en quelque degré que ce soit, déclarant qu'elles seront celles des leur naissance sans avoir besoin pour cela d'aucune promotion. Je déclare de La Princesse Czarienne N.N. ... Épouse du Prince Czarien ... fils unique du Czaar, Monseigneur, Première Dame Grand Croix de l'Ordre, et je veux qu'à l'avenir toutes les Princesses Czariennes Épouses des Princes héritiers de l'Empire, le soient pareillement dès le jour de leur mariage, ipso facto et sans autre promotion.

9. Je réserve à moi et à toutes les Grandes Maîtresses après moi, le droit de créer les autres sis Dames Grand Croix et toutes les Dames Chevalières à nôtre volonté.

10. Je réserve pareillement à moi, et à toutes les Grandes Maîtresses après moi, le droit de destituer à volonté celle Dame Grand Croix et celle [1.240 ob.] Dame Chevalière qu'il nous plaira. Mais quant aux Princesses du Sang Royal Impérial, ni moi, ni les autres Grandes Maîtresses ne pouvons les destituer.

11. Chaque Dame en recevant l'Ordre recevra aussi la Croix qu'elle devra porter, et quand elle viendra à mourir, la Croix sera rendue a la Grande Maîtresse. La même chose se fera en cas de destitution.

12. La première dépense de toutes ces croix sera faite pour moi et par toutes les Grandes Maîtresse après moi ; mais chaque Dame sera tenue d'entretenir sans dépérissement celle qui lui aura été donnée.

13. Après moi, et dans tous les cas où il pourrait arriver que le Czar régnant ne serait point mariée, La Princesse Czarienne, Épouse du Prince Czarien, et à son défaut la plus ancienne Princesse [1.241] du Sang Imperial exercera la Vicariat de l'Ordre, et le gardera jusqu'à ce qu'il y ait une Grande Maîtresse. Elle pourra aussi remplir les places vacantes ou qui viendront à vagues.

14. Toutefois La Princesse Grande Vicaire ne pourra destituer à volonté aucune Dame Grand Croix, ni aucune Dame Chevalière, mais si quelqu'une s'en était rendue par sa mauvaise conduite, en ce cas la Prince[sse] Grande Vicaire en donnera avis au Czar et après avoir reçu ces ordres là dessus, elle pourra la destituer.

15. Les destitutions se feront sans autre formalité que d'envoyer redemande la Croix de l'Ordre à la Dame destituée, ce qui sera fait par le secrétaire, lequel après avoir reçu la dite Croix la rapportera à la Grande Maîtresse, ou à la Grande Vicaire et lui fera son rapport. 
16. Pour cette fonction et autres [1. 241 ob.] semblables de l'Ordre il sera créé un officier noble sous le titre de Secrétaire et Trésorier de l'Ordre de la Délivrance. Cet officier tiendra un Registre fidèle de toutes les choses qui concerneront l'Ordre à commencer par son institution, et de toutes les personnes qui y seront reçues, comme aussi de toutes les places qui deviendront vacantes, soit par mort, soit par destitution. Il aura soin de faire les croix, dont la Grande Maîtresse aura besoin ; il tiendra et la garde toutes celles qui seront vacantes ; il assistera aux vœux des Dames Grand Croix, et des Dames Chevalières, et il en dressera des actes qui seront enregistrés au livre de l'Ordre. Enfin il écrira toutes les lettres et expédiera toutes les affaires de l'Ordre sur le commandement de la Grande Maîtresse ou de la Grande Vicaire. Ses gages seront... [1.242] par an pour lui et ... aussi par an pour deux curseurs de l'Ordre dont l'emploi sera d'aller avertir les Dames Chevalières du jour et de l'heure qu'elle devront se trouver à la Cour, et autres services de même nature. Permis au dit Secrétaire de donner aux Dames Grand Croix et aux Dames Chevalières des actes qui feront foi du serment qu'elles auront prêté, et de se faire payer pour son expédition la somme de ... pour chaque Dame Chevalière.

Quant aux voyages que ledit Secrétaire pourra être obligé de faire hors de 1 a Cour, pour aller redemander l'Ordre aux Dames qui seront destituées, il s'en fera payer par elles sur le pied de l'éloignement où elles se trouveront, et il lui sera accordé pour cela ... par verste.

Telles sont les constitutions [1. $242 \mathrm{ob}$.] sur lesquelles j'établis, je fonde, et j'institue le Très-noble Ordre de la Délivrance priant Dieu de vouloir tenir en la sainte garde toutes de personnes qui y seront initiées ; de leur donner les grâces nécessaires pour en remplir dignement les devoirs et diriger le tout à la gloire de son saint nom.

Donné à ... Le ...

\section{Appendix II*. [Л. 174] ПРОЕКТ ОБ ОРДЕНЕ КАВАЛЕРИИ КОТОРОЙ МОЖЕТ УЧРЕЖДЕН БЬЫТЬ ПРИ ДВОРЕ ЕГО ЦАРСКОКОГО ВЕЛЕЛИЧЕСТВА ВО славу бога всемогущему и всеблажайшему}

ЕКАТЕРИНА МИЛОСТИЮ БОЖИЮ ЦАРИЦА СИ ПРОЧАЯ> ВСЕРОССИЙСКАЯ И ПРОТЧАЯ.
ВСЕМ КО<ТОРЫЕ СИЕ УВИДЯТ>МУ ВЕДАТЬ НАДЛЕЖИТ ПОЗДРАВЛ СЕНИЕ>ЯЕМ.

<ВСЕМ БЕЗСУМНИТЕЛЬНО> ИЗВЕСТНО ЕСТЬ ВСЕМ, КОИМ ОБРАЗОМ ВСЕМОГУЩИЙ БОГ БЛАГОВОЛИЛ СВОЕ ВЕЛИКОЕ И ЩЕДРОЕ БЛАГОСЛОВЕНИЕ ИЗОБИЛЬНО ОКАЗАТЬ НАД ПРЕСВЕТЛЕЙШИМ И ДЕРЖАВНЕЙШИМ ВЕЛИКОМ ГОСУДАРЕМ ЦАРЕМ ПЕТРОМ АЛЕКСЕЕВИЧЕМ, МИЛОСТИЮ БОЖИЮ И ПРОЧАЯ, МОИМ ПОЧТЕННЕЙШИМ ГОСУДАРЕМ И ЛЮБЕЗНЕЙШИМ СУПРУГОМ, ИБО ОНАГО ЯКО ЧЮДОТВОРНО ОТ САМОЙ ЮНОСТИ ЕГО ЗАЩИЩАЛ И СПАС ОТ КОВАРСТВЕННЫХ НАВЕТОВ <ДОМАШНИХ ЕГО $>$ КАК НЕПРИЯТЕЛ <ЕЙ>ЬСКИХ ТАК И ДОМАШНИХ БУНТОВ УЧИНЕННЫХ <ОТ НЕКОТОРЫХ ИЗ ЕГО ПОДДАННЫХ>, И ОТ ТЫСЯЧЕКРАТНЫХ СТРАХОВ СЛУЧИВШИХСЯ [Л. 174 ОБ] ЕМУ В ДОЛГОВРЕМЕННЫХ <ВОЙНАХ > КРОВАВЫХ ВОЙНАХ, В КОТОРЫХ БЫЛ ПЕРСОНАЛЬНО САМ ОБЯЗАН. 
Я МЕЖДУ ПРОЧИМ СЛУЧАЙ ИМЕЛА ЧЕСТЬ ПОСЛЕДОВАТЬ ЗА НИМ В МЕСЯЦЕ ИЮЛЕ 1711 ГОДА КОГДА <УЧИНИЛ ПОДВИГ С ОСОБЛИВЫМ ВЕЛИКОДУШИЕМ К РЕКЕ ПРУТУ ДЛЯ ПРЕСЕЧЕНИЯ ПУТИ СУПОСТАТАМ ВЕРЫ, КОТОРЫЕ В ГОТОВНОСТИ БЫЛИ ВСТУПИТЬ ВОЙНОЮ ${ }^{104}><$ <ОГДА ИЗ СВОЕГО ВЕЛИКОДУШИЯ ДЛЯ ПРЕСЕЧЕНИЯ ПУТИ СУПОСТАТАМ ВЕРЫ ВСТУПАЮЩИМ В ПОЛЬШУ ВЕЛИКОДУШНО ПОДВИГ УЧИНИВ ДО САМОЙ РЕКИ ПРУТА, ЧУТЬ ОТ НЕИСЧИСЛИМОГО МНОЖЕСТВА ТЕХ ${ }^{105}>$ НА СОПРОТИВЛЕНИЕ СУПОСТАТОМ

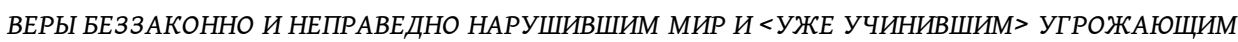
НАПАДЕНИЕ < [illegible]> РУССКИЕ ЗЕМЛИ < [illegible] ОРУЖИЕ> УСКОРИЛ СВОИМ ПОДВИГОМ ДАЖЕ ДО САМОЙ РЕКИ ПРУТА, ГДЕ ОТ НЕИСЧИСЛИМОГО МНОЖЕСТВА ТЕХ СУПОСТАТОВ ВЕРЫ БЫЛ ТОГО ЧАСУ ОКРУЖЕН, И НЕМОЧНО ИЗРЕЩИ, В КАКИХ КРАЙНОСТЯХ ТОГДА МЫ ОБРЕТАЛИСЯ, ИБО < [illegible]> ВЕСЬМА НИКАКОЙ ПРОПОРЦИИ НЕ БЫЛО МЕЖДУ НАШИМИ СИЛАМИ И ИХ СУПОСТАТСКИМИ; <ВТОРОЕ> К ТОМУ Ж ПРОПИТАНИЕ НАМ ОТ ВСЕХ СТРАН ВСЕМЕРНО БЫЛО ПРЕСЕЧЕНО, И ОДНИМ СЛОВОМ ЗАКЛЮЧИТЬ, ЧТО <НИКАКАЯ> ВСЯ ХРАБРОСТЬ, КОТОРАЯ МОЖЕТ ЧЕЛОВЕЧЕСКИ ПОМЫСЛИТЬСЯ, ЯВЛЯЛАСЬ БЫТЬ БЕЗДЕЙСТВИТЕЛЬНА К ПОМОЩИ НАШЕЙ, ТАК ЧТО СВОБОЖДЕНИЕ НАШЕ ОТ ТАКИХ СМЕРТНЫХ СТРАХОВ НЕ МОГЛО НИОТКУДУ ПРОИЗОЙТИ, КРОМЕ ОТ ЕДИНОГО БОГА, КОТОРОЕ ОН НАМ ЯВНО ДАРОВАЛ; И ПОСЛЕ БОЮ, КОТОРОЙ ПРОДОЛЖАЛСЯ ТРИ ДНИ, И ПРИ КОТОРОМ Я ПРИСУДСТВЕННА И ОЧЕВИДНАЯ СВИДЕТЕЛЬНИЦА БЫЛА ХРАБРОСТИ НЕПОБЕДИМОЙ <МОЕГО АВГУСТЕЙШЕГО > [Л. 175] <СУПРУГА И ЕГО>МУЖЕСТВА БЛАГОРАЗУМИЯ <И КРЕПОСТИ> ГЕРОИЧЕСКОЙ МОЕГО АВГУСТЕЙШЕГО СУПРУГА <В ТО ВРЕМЯ ПОЛНОЕ СТРАХУ>.

ПО ОКОНЧАНИИ ТОГО <СВИРЕПОГО >КРОВАВОZО БОЮ <ВОЗСИЯЛА НЕИЗРЕЧЕННАЯ РАДОСТЬ $><$ УВИДЕТЬ $><$ УРИТЬ $><$ СИЯЮЩЕЙ ВОЗСИЯВШЕЙ [illegible] $><$ С НЕИЗРЕЧЕННОЮ РАДОСТИЮ УЗРИЛА ВОЗСИЯНИЕ СВЕТУ>ВОЗЫМЕЛА НЕИЗРЕЧЕНУЮ РАДОСТЬ ВИДЕТЬ ДАРОВАНИЕ [illegible] НАМ СИЯНИЕ СВЕТА ПОСЛЕДУЮЩЕГО ПОТОМУ [illegible] МиРу.

ТОГО РАДИ И ДЛЯ ВЫШЕОБЪЯВЛЕННЫХ ПРИЧИН Я ВОЗЖЕЛАЛА УТВЕРДИТЬ ВЕЧНУЮ ПАМЯТЬ СЕГО ЗНАМЕНИТОГО СВОБОЖДЕНИЯ И ЗАБЛАГОРАЗСУДИЛА УЧРЕДИТЬ И УСТАНОВИТЬ ЯКО ЖЕ ДЕЙСТВИТЕЛЬНО УЧРЕЖДАЮ И ПОСТАНОВЛЯЮ СИМ НАСТОЯЩИМ ВО СЛАВУ БОГУ ВСЕМОГУЩЕМУ И В ЧЕСТЬ <БЛАЖЕННЕЙШЕЙ>СВЯТОЙ МУЧЕНИЦЫ < МОЕЙ ПАТРОНЫ> ЕКАТЕРИНЫ <АЛЕКСАНДРИЙСКОЙ, КОТОРОЙ ИМЕНЕМ НАЗЫВАЮСЯ > ОР ДЕН КАВАЛЕРИИ КОТОРОЙ БУДЕТ СОЧИНЕН ИЗ ДАМ < [illegible]> ЧЕСТНЫХ И БОГОБОЯЗНЕННЫХ, ЗАМУЖНЫХ И БЕЗЗАМУЖНЫХ СЛЕДУЮЩИМ ОБРАЗОМ.

1. ВРУЧАЮ ПОКОРНО СЕЙ ОРДЕН ПОД ПРОТЕКЦИЮ ЦАРЯ МОЕГО ГОСУДАРЯ И ОНОЙ <ПРИНЯТЬ> ПОЧЕСТЬ [Л. 175 ОБ] ЗА ЗНАК МОЕЙ ГОРЯЧЕЙ ЛЮБВИ И ГЛУБОКАГО ПОЧИТАНИЯ, КОТОРОЕ Я К НЕМУ ИМЕЮ; И В ТОМ ВИДУ ОНЫЙ ЗА БЛАГО ПРИЗНАТЬ И ПОДТВЕРДИТЬ, ДАБЫ СИЛОЮ ЕГО УСТАВОВ ИМПЕРАТОРСКИХ, ОНОЙ ПРОДОЛЖЕН И СОДЕРЖЕН БЫЛ ВЕЧНО В ИМПЕРИИ РОССИЙСКОЙ.

2. ПОМЯНУТЫЙ ОРДЕН НАЗЫВАТИСЯ БУДЕТ ОР ДЕН СВОБОЖДЕНИЯ l'ordre de la delivrance В ПАМЯТЬ ОНАГО СВОБОЖДЕНИЯ, КОТОРОЕ ВСЕМОГУЩИЙ БОГ БЛАГОВОЛИЛ ДАРОВАТЬ <ЦАРЮ МОЕМУ ГОСУДАРЮ> ЕГО:Ц:В: В ЗНАТНОЙ И КРОВАВОЙ БАТАЛИИ ПРУТСКОЙ, ПРИ КОТОРОЙ Я ПРИСУТСТВОВАЛА И ОЧЕВИДНИЦА БЫЛА, ТАКЖЕ И В ПАМЯТЬ ВСЕХ ПРОЧИХ СВОБОЖДНИЙ, ПРЕДШЕСТВУЮЩИХ ПРЕД СИМ. 
3. <СЕЙ ОРДЕН БУДЕТ СОСТОЯТЬ ИЗ>СЕЙ ОРДЕН БУДЕТ СОДЕРЖАТЬ В СЕБЕ ОДНУ ПЕРВЕНСТВУЮЩУЮ ПЕРСОНУ, ИЛИ ПО ФРАНЦУЗСКИ (ГРАНД МЕТРЕССУ) ${ }^{106}$, И СТОЛЬКО ДАМ ОТ БОЛЬШОГО КРЕСТА, СКОЛЬКО ЕСТЬ ПРИНЦЕСС КРОВИ ЦАРСКОЙ, $<$ [illegible]> 12 ДРУГИХ ДАМ БОЛЬШОГО КРЕСТА, И 94 ДАМЫ КАВАЛЕР<ИЦЫ>СТВЕННЫЕ ВСЕ <ДВОР ЯНСКОГО>ШЛЯХЕТНОГО УРОЖДЕНИЯ. [Л. 176]

4. ЗНАК ОРДЕНА БУДЕТ КРЕСТ БЕЛОЙ В ЗНАМЕНОВАНИЕ ЧИСТОТЫ; В ПОЛЕ ПУРПУРОВЫМ < [illegible] ПОКАЗУЕТСЯ>ЯВЛЯЮЩЕЕ КОТОРАЯ БУДЕТ ОНОЙ НОСИТЬ ДОЛЖНА ЛУЧШЕ УМЕРЕТЬ, НЕЖЕЛИ ПРЕНЕБРЕЩИ СВОЕ ОБЕЩАНИЕ. СОТВОРЕНИЕ СВЕТА, КАК НАПИСАНО В ПЕРВОЙ ГЛАВЕ ЕНЕЗИСА БУДЕТ ИЗОБРАЖАТЬ В СРЕДИНЕ КРЕСТ, А В САМОМ ЦЕНТРЕ ДРУГОЙ МЕНШЕЙ КРЕСТ УКРАШЕННОЙ ЛУЧАМИ ЗНАМЕНУЮЩЕЙ СВЕТ ЕВАНГЕЛЬСКИЙ, КОТОРОЙ ДАДЕСЯ ВО СВЕТИЛО НАРОДАМ ДА И СПАСАНИЕ ЯЗЫКАМ ДО КОНЦА ВСЕЛЕННОЙ РЕЧЕ ПРОРОК ИСАЙЯ В ГЛАВЕ 46 [sic! - I.F., E.Z.] 6 ВИРШ. МЕЖДУ СПИЦАМИ КРЕСТОВЫМИ ПОСТАВЛЕНЫ БУДУТ СИЕ ЧЕТЫРЕ БУКВЫ D.S.F.R., КОТОРЫЕ ЕСТЬ СЛОВА ПЕРВОНАЧИНАЮЩИЕСЯ В ПСАЛМЕ 19 Domine salvum faC Regem, ГОСПОДИ СПАСИ ЦАРЯ. ВСЯКАЯ ДАМА КАВАЛЕР<ИЦА>СТВЕННАЯ БУДЕТ НОСИТЬ СЕЙ КРЕСТ НА ПЛАТЬЕ ПО ЛЕВОЙ СТОРОНЕ ПРИ СЕРДЦЕ, И ПРИВЯЗАН БУДЕТ БЕЛОЮ ЛЕНТОЮ, НА КОТОРОЙ БУДУТ НАПИСАНЫ [(Л. 176 ОБ] < [illegible]> ЗОЛОТЫМИ БУКВАМИ СИЕ СЛОВА < [illegible] СВЕТ>Pro amore $<$ conjugal $>107$ et patria $3 \mathrm{~A}$ ЛЮБОВЬ И ОТЕЧЕСТВО.

КРЕСТЫ ДАМ БОЛЬШОГО КРЕСТА БУДУТ БОЛЬШЕ И ИНЫМ МАНЕРОМ НЕЖЕЛИ КАВАЛЕР<[illegible]>CТВЕННЫХ ТАКОЖДЕ И < [illegible]>УКРАШЕНИЕ БУДЕТ БОЛШЕ ЦЕНОЮ, А КРЕСТ ПЕРВЕНСТВЕННЫЯ <ДАМЫ> <ГЛАВЫ>ПЕРСОНЫ ИЛИ ПО ФРАНЦУСКИ ГРАНД МЕТРЕСС БУДЕТ ОТМЕНЕН ОТ ВСЕХ КАК ВЕЛИКОСТИЮ ТАК И В УКРАШЕНИИ БОГАТСТВОМ, СИЕ ТРИ РАЗНЫЕ СТАТИ КРЕСТОВ ИЗОБРАЖЕНЫ ЗДЕСЬ НА ОБРАЗЦЕ. 108

5. ДОЛЖНОСТЬ КАЖДОЙ ДАМЫ БОЛЬШОГО КРЕСТА И КАЖДОЙ ДАМЫ КАВАЛЕР<illegible>CТВЕННОЙ ИМЕЕТ БЫТЬ, ПЕРВОЕ, БЛАГОДАРИТЬ БОГА ВО ВСЕ ДНИ <3А ЧЮДОДЕЙСТВЕННЫЯ>ЗА МИЛОСТИВЫЯ СВОБОЖДЕНИЯ <И ЗА illegible>, КОТОРЫЯ ОН ДОНЫНЕ ДАРОВАЛ <МОЕМУ ГОСУДАРЮ>ЕГО:Ц:В МОЕМУ ГОСУДАРЮ; ВТОРОЕ, <ПРОСИТЬ>МОЛИТЬ БОГА ТАКОЖДЕ ВО ВСЕ ДНИ О СОБЛЮДЕНИИ ЕГО ОСВЯЩЕННОЙ ОСОБЫ, < [illegible]>О ЗДРАВИИ ЕГО И МНОГОЛЕТСВИИ, И О БЛАГОПОЛУЧИИ ЕГО ОРУЖИЯ И ДЕЛ; ТАКОЖЕ И О БЛАГОПОЛУЧИИ, О ЗДРАВИИ И МНОГОЛЕТСВЕ <ГОСУДАРЯ ЦАРЕВИЧА И ЕГО СУПРУГИ И ПРИНЦЕВ И ПРИНЦЕСС ЦАРСКОЙ ФАМИЛИИРЕГО НАСЛЕДНИКОВ И ВСЕЙ ЕГО ИМПЕРАТОРСКОЙ ФАМИЛИИ; ТРЕТИЕ, ВО ВСЕМ ТОМ ЖЕ НАМЕРЕНИИ ПО ВСЕ ВОСКРЕСНЫЯ ДНИ ПРОГОВАРИВАТЬ ТРИЖДЫ ОТЧЕ НАШ В ЧЕСТЬ СВЯТЫЯ ТРОИЦЫ; ЧЕТВЕРТОЕ, ТРУДИТСЯ СКОЛЬКО ВОЗМОЖНО О ПРИВРАЩЕНИИ < [illegible]> НЕСКОЛЬКИХ НЕВЕРНЫХ [Л. 177] К ВЕРЕ <НАШЕГО СПАСИТЕЛЯ ИИСУСА ХРИСТАРНАШЕЙ БЛАГОЧЕСТИВОЙ УПОТРЕБЛЯЯ К ТОМУ ДОБРОДЕТЕЛЬНЫЕ СПОСОБЫ И УВЕЩАНИЯ И ОТНЮДЬ НИКАКИМ УГРОЖЕНИЕМ, НИЖЕ ПРИНУЖДЕНИЕМ; ПЯТОЕ, СВОБОЖДАТЬ ОДНОГО ХРИСТИАНИНА ИЗ ПОРАБОЩЕНИЯ <ТУРЕЦКАГО Р ВАРВАРСКАГО ВЫКУПАЯ ЗА СВОИ СОБСТВЕННЫЯ ДЕНЬГИ.

6. СВЕРХ ТОГО КАЖДАЯ ДАМА КОТОРАЯ ПРИМЕТ ОРДЕН УЧИНИТЬ ТОРЖЕСТВЕННОЕ ОБЪЕДИНЕНИЕ ПРЕБЫТЬ ВЕРНОЙ <ЦАРЮ>ЕГО:Ц:В: И ЧТО НИКОГДА НЕ СООБЩИТСЯ НИ В КАКОЙ УМЫСЕЛ ПРОТИВ ЕГО ОСОБЫ НИ ПРОТИВ ЕГО ВЛАСТИ 
САМОДЕРЖАВНЫЯ < [illegible]>. СИЕ ОБЕЩАНИЕ ДА УЧИНИТСЯ С ПРИСЯГОЮ НА СВЯТОМ ЕВАНГЕЛИИ В ПРИСУТСТВИИ <[illegible] illegible>ПЕРВОЙ ГЛАВЫ<illegible> ОРДЕНА И ПРИ ТОЛИКИХ ДАМАХ БОЛЬШАГО КРЕСТА, ИЛИ

КАВАЛЕР СНЫХ СТОВЕННЫХ, СКОЛЬКО В ТО ВРЕМЯ ПРИ ДВОРЕ ОБРЕТАТИСЯ БУДЕТ. К ТОМУ Ж ПРИЗВАН БУДЕТ <ПАТРИАРХ [illegible]> КОТОРОЙ НИ ЕСТЬ ИЗ НАЧАЛЬНЫХ ДУХОВНЫХ, <illegible> ДАБЫ ПРИСУТСТВЕНЕН ТОЙ ПРИСЯГЕ БЫЛ, ДЛЯ ОТПРАВЛЕНИЯ ДУХОВНОЙ ЦЕРЕМОНИИ. ДАМЫ, КОТОРЫЯ БУДУТ ОТСУТСТВЕННЫ, МОГУТ ПРИСЯГУ СВОЮ УЧИНИТЬ ЧРЕЗ ОПРЕДЕЛЕННЫХ К ТОМУ [Л. 177 ОБ]; А КОТОРЫЯ ВЕСЬМА МОЛОДЫ БУДУТ В МЛАДОЛЕТСТВЕ, ОНЫЯ ОТ ТОГО БУДУТ УВОЛЕНЫ ДО 16 ЛЕТ.

7. Я ПРЕДУ ДЕРЖИВАЮ СЕБЕ ОНОЙ И ПРОЧИМ СЦАРИЦАМ>ПОСЛЕДОВАТЕЛЬНИЦАМ ПО МНЕ ДОСТОИНСТВО ВЕЛИКОЙ ГОСПОЖИ ОРДЕНА.

8. $<$ Illegible> Я <ПРИЗНАЮ>ПРИЗЫВАЮ К ДОСТОИНСТВУ ДАМ БОЛЬШАГО КРЕСТА ВСЕХ ПРИНЦЕСС КРОВИ ЦАРСКОЙ <illegible> ОБЪЯВЛЯЯ ОНЫХ БЫТЬ ТОГО ОРДЕНА ОТ САМАГО ИХ РОЖДЕНИЯ БЕЗ ВСЯКАГО ПОСТАНОВЛЕНИЯ НАРОЧНАГО СПРИ ТОМ ЖЕ ОБЪЯВЛЯЮ ПРИНЦЕССУ ЦЕСАРЕВИЧЕВУ СУПРУГУ ГОСУДАРЯ ЦЕСАРЕВИЧА [illegible] ПЕРВОЮ ДАМОЮ БОЛЬШАГО КРЕСТА СЕГО ОРДЕНА И ХОЩУ ДАБЫ ВПРЕДЬ ВСЕ ПРИНЦЕССЫ ЦЕСАРЕВИЧЕВЫ СУПРУГИ ПРИЦНЕВ НАСЛЕДСТВЕННЫХ ИМПЕРАТОРА РОССИЙСКАГО БЫЛИ РАВНЫМ ЖЕ ОБРАЗОМ СЕГО ОРДЕНА С ПЕРВОГО ИХ СВОЕГО СУПРУЖЕСТВА САМИ СОБОЮ И БЕЗ ВСЯКАГО ПРОИЗВОЖДЕНИЯ К TOMY>. ${ }^{109}$

9. Я ПРЕДУДЕРЖИВАЮ СЕБЕ ПРАВО И ПРОЧИМ ВЕЛИКИМ ГОСПОЖАМ ОРДЕНА ПОСЛЕ МЕНЯ ПОСТАВЛЯТЬ ПРОЧИХ 12 ДАМ БОЛЬШАГО КРЕСТА И ВСЕХ КАВАЛЕР <НЫХ>СТВЕННЫХ ДАМ <illegible>КОТОРЫЕ НАМ УГОДНЫ СУТЬ.

10. Я ПРЕДУДЕРЖИВАЮ ТАКОЖДЕ СЕБЕ И ВСЕМ ВЕЛИКИМ ГОСПОЖАМ ПОСЛЕ МЕНЯ ПРАВО ЛИШАТЬ ТОГО ОРДЕНА, ПО ИЗВОЛЕНИЮ, ТАКУЮ ДАМУ БОЛЬШАГО КРЕСТА И ТАКУЮ ДАМУ КАВАЛЕР<НУЮ>СТВЕННУЮ, КАК НАМ УГОДНО, НО ЧТО ЖЕ ПРИНАЛЕЖИТ ДО ПРИНЦЕСС КРОВИ ЦАРСКОЙ ТО НИ Я НИЖЕ ПРОЧИЯ НАЧАЛЬСТВЕННЫЯ ГЛАВЫ ДА НЕ ВОЗМОГНУТ ОНЫХ ТОГО ЛИШИТЬ.

11. КАЖДАЯ ДАМА ПРИ ПОЛУЧЕНИИ ОРДЕНА, ПОЛУЧИТ ТАКОЖДЕ КРЕСТ КОТОРОЙ ИМЕЕТ НОСИТЬ, А КОГДА УМРЕТ, ТОТ КРЕСТ ИМЕЕТ ВОЗВРАЩЕН БЫТЬ ВЕЛИКОЙ ГОСПОЖЕ, РАВЕНСТВЕННО ТОЖ ИМЕЕТ ЧИНИТИСЯ В СЛУЧАЕ ЛИШЕНИЯ. [Л. 178]

12. ПЕРВОЕ ИЖДИВЕНИЕ НА СИИ [Л. 178] КРЕСТЫ УЧИНЕНО БУДЕТ ОТ МЕНЯ, И ОТ ВСЕХ ВЕЛИКИХ ГОСПОЖЕЙ ПОСЛЕ МЕНЯ. НО КАЖДАЯ ДАМА ДОЛЖНА БУДЕТ СОДЕРЖАТЬ В <illegible>ЦЕЛОСТИ ОНОЙ КРЕСТ, КОТОРОЙ БУДЕТ ЕЙ ДАН. $<13$. ПОСЛЕ МЕНЯ И ВО ВСЯКИХ СЛУЧАЯХ В КОТОРЫХ МОГЛО СЛУЧИТЬСЯ ЧТО ЦАРЬ НЫНЕ ГОСУДАРСТВУЮЩИЙ НЕ ИМЕЛ Б СУПРУГИ ТО ПРИНЦЕССА СУПРУГА ГОСУДАРЯ ЦЕСАРЕВИЧА, А ЕЖЕЛИ ОНОЙ НЕ <illegible> ТО САМАЯ СТАРШАЯ ПРИНЦЕССА КРОВИ ЦАРСКОЙ ИМЕЕТ ОТПРАВЛЯТЬ НАМЕСТНИЧЕСТВО СЕГО ОРДЕНА И СОДЕРЖАТЬ ОНОЙ ПОКА БУДЕТ НАЧАЛЬНАЯ ГОСПОЖА И ВОЗМОЖЕТ РАЗДАВАТЬ УПАЛЫЯ МЕСТА И КОТОРОЕ ВПРЕДЬ БУДЕТ.>

13. ПОСЛЕ МЕНЯ И ВО ВСЯКИХ СЛУЧАЯХ В КОТОРЫХ БЫ МОГЛО СЛУЧИТСЯ ЗА НЕБЫТИЕМ <illegible> ГОСПОЖИ ОРДЕНА: ТОГДА ПЕРВАЯ ПРИНЦЕССА КРОВИ ИМЕЕТ ОТПРАВЛЯТЬ НАМЕСТНИЧЕСТВО СЕГО ОРДЕНА И СОДЕРЖАТЬ ОНОЙ ПОКА <illegible> НАЧАЛЬНАЯ <ГЛАВА> ГОСПОЖА И ВОЗМОЖЕТ РАЗДАВАТЬ УПАЛЫЯ МЕСТА И КОТОРОЕ ВПРЕДЬ БУДЕТ. 110 
14. ОДНАКОЖ ОНАЯ ПРИНЦЕССА, ВЕЛИКАЯ НАМЕСТНИЦА, НЕ ВОЗМОЖЕТ ЛИШИТЬ ПО ВОЛЕ СВОЕЙ НИКАКУЮ ДАМУ БОЛЬШАГО КРЕСТА И НИКАКУЮ ДАМУ КАВАЛЕРСТВЕННУЮ. А ЕЖЕЛИ СЛУЧИТСЯ ЧТО КОТОРАЯ НИ ЕСТЬ ИЗ ТЕХ ДАМ УЧИНИТ СЕБЯ НЕДОСТОЙНОЮ СВОИМ НЕПОРЯДОЧНЫМ ПОВЕДЕНИЕМ; ТО В ТАКОМ СЛУЧАЕ ОНАЯ ПРИНЦЕССА ВЕЛИКАЯ НАМЕСТНИЦА, О ТОМ ПОДАСТ ИЗВЕСТИЕ <ЦАРЮ>Ц:В:, И ПО ПОЛУЧЕНИИ НА ТО ОТ НЕГО УКАЗА, ДА ВОЗМОЖЕТ ЛИШИТЬ ТАКУЮ ДАМУ СЕГО ОРДЕНА. [Л. 178 ОБ]

15. ЛИШЕНИЕ ОРДЕНА ИМЕЕТ ЧИНИТЬСЯ БЕЗ ВСЯКОЙ ИНОЙ ЦЕРЕМОНИИ, ТОКМО ЧТО ПОШЛЕТСЯ ВЗЯТЬ КРЕСТ ОР ДЕНА ОТ ТОЙ ДАМЫ, КОТОРАЯ ЛИШЕНА БУДЕТ, ЧТО ИМЕЕТ УЧИНИТСЯ ЧРЕЗ СЕКРЕТАРЯ, КОТОРОЙ ПРИНЯВ ПОМЯНУТЫЙ КРЕСТ, ПРИНЕСЕТ НАЗАД, И ВРУЧИТ ВЕЛИКОЙ ГОСПОЖЕ ИЛИ ВЕЛИКОЙ НАМЕСТНИЦЕ, И О ТОМ УЧИНИТ ОНОЙ СВОЕ ДОНОШЕНИЕ.

16. ДЛЯ СЕГО ЧИНУ И ПРОТЧАГО ПОТРЕБНАГО К СЕМУ ОРДЕНУ, ОПРЕДЕЛЕН БУДЕТ ОФИЦЕР <illegible> ПОД ТИТУЛОМ СЕКРЕТАРЯ И КАЗНАЧЕЯ ОРДЕНА СВОБОЖДЕНИЯ. СЕЙ ОФИЦЕР БУДЕТ ДЕРЖАТЬ ЗАПИСКУ ПОДЛИННУЮ О ВСЕМ ЧТО КАСАТЬСЯ БУДЕТ ДО ОРДЕНА ПО УСТАВУ ОНАГО, И ОБО ВСЕХ ТЕХ ПЕРСОНАХ, КОТОРЫЯ ВО ОНОЙ ПРИНЯТЫ БУДУТ; ТАКОЖДЕ И О МЕСТАХ УПАЛЫХ, КОТОРЫЯ СЛУЧАТСЯ ИЛИ ЧРЕЗ СМЕРТЬ ИЛИ ЧРЕЗ ЛИШЕНИЕ ОРДЕНА. ОН ЖЕ ДА ИМЕЕТ ПОПЕЧЕНИЕ [Л. 178 ob] ПРИКАЗЫВАТЬ ДЕЛАТЬ КРЕСТЫ, КОТОРЫЯ ВЕЛИКОЙ ГОСПОЖЕ БУДУТ ПОТРЕБНЫ, И БУДЕТ ИМЕТЬ У СЕБЯ В СОБЛЮДЕНИИ ВСЕ ТЕ КРЕСТЫ, КОТОРЫЯ ОСТАНУТСЯ ОТ УПАЛЫХ. ОН ЖЕ ИМЕЕТ ПРИСУТСТВОВАТЬ ПРИ ОБЕЩАНИЯХ ДАМ БОЛЬШАГО КРЕСТА И ДАМ КАВАЛЕРСТВЕННЫХ, И БУДЕТ ПИСАТЬ ГРАМОТЫ ЖАЛОВАННЫЯ, КОТОРЫЯ БУДУТ ЗАПИСАНЫ В КНИГУ ОРДЕНА. К ТОМУ ЖЕ ОН БУДЕТ ОТПРАВЛЯТЬ ВСЕ ДЕЛА ОРДЕНА ПО УКАЗУ ВЕЛИКОЙ ГОСПОЖИ ИЛИ ВЕЛИКОЙ НАМЕСТНИЦЫ. ЖАЛОВАНЬЯ ГОДОВОГО ЕМУ...

ДВОИМ ЖЕ ХОДАКАМ ОРДЕНА, КОТОРЫХ ЧИН СОСТОЯТЬ БУДЕТ В ТОМ, ЧТОБ ХОДИТЬ К ДАМАМ КАВАЛЕРСТВЕННЫМ С ОБЪЯВЛЕНИЕМ, В КОТОРОЙ ДЕНЬ И КОТОРОЙ ЧАС ОНЫЯ ИМЕЮТ БЫТЬ КО ДВОРУ, И ДЛЯ ПРОТЧЕЙ РАВНОЙ УСЛУГИ. ПОЗВОЛЕНО ДА БУДЕТ СЕКРЕТАРЮ ДАВАТЬ ДАМАМ БОЛЬШАГО КРЕСТА И ДАМАМ КАВАЛЕРСТВЕННЫМ АКТЫ, КОТОРЫЯ БУДУТ СВИДЕТЕЛЬСТВОВАТЬ О УЧИНЕННОЙ ИХ ПРИСЯГЕ. И ЗА ТОТ СВОЙ ТРУД БРАТЬ ЗАПЛАТУ, А ИМЯННО ОТ КАЖДОЙ ДАМЫ БОЛЬШОГО КРЕСТА СУММУ... [Л. 179]

17. ЗА КАЖДУЮ ДАМУ КАВАЛЕРСТВЕННУЮ...

18. А КОГДА ПОМЯНУТОЙ СЕКРЕТАРЬ МОЖЕТ БЫТЬ ПРИНУЖДЕН БУДЕТ ЕХАТЬ ВНЕ ДВОРА ДЛЯ ВЗЯТЬЯ ОРДИНА ОТ ДАМ КОТОРЫЯ ОНАГО ЛИШЕНЫ БУДУТ, ТОГДА ЗА ТОТ ЕГО ТРУД ПЛАЧЕНО БУДЕТ СМОТРЯ ПО ДАЛЬНОСТИ МЕСТА, ГДЕ ОНЫЯ ДАМЫ ОБРЕТАТЬСЯ БУДУТ, А ИМЯННО ЗА ВСЯКУЮ ВЕРСТУ...

СЕЙ ЕСТЬ УСТАВ НА КОТОРОМ Я УЧРЕЖДАЮ [illegible] И ПОСТАНОВЛЯЮ ШЛЯХЕТНЕЙШИЙ ОРДИН СВОБОЖДЕНИЯ МОЛЯ БОГА ДАБЫ БЛАГОВОЛИЛ СОДЕРЖАТЬ ПОД СВОИМ СВЯТЫМ ЗАЩИЩЕНИЕМ ВСЕХ ТЕХ ПЕРСОН КОТОРЫЯ ВО ОНОЙ ПРИНЯТЫ БУДУТ И ДАРОВАЛ БЫ ИМ СВОЮ МИЛОСТЬ ДАБЫ ДОСТОИНСТВЕННО МОГЛИ ИСПОЛНИТЬ СВОИ ДОЛЖНОСТИ ВО СЛАВУ ИМЯНИ СВОЕГО СВЯТОГО. 


\section{NOTES}

1. Richard Wortman, "The Redefinition of the Sacred: Eighteenth-Century Russian Coronations," in Alain Boureau, Claudio Sergio Ingerflom, eds., La royauté sacrée dans le monde chrétien. Colloque de Royaumont, mars 1989 (P.: Éd. de l'École des Hautes Études en Sciences Sociales, 1992), 149-156; and especially his Scenarios of Power: Myth and Ceremony in Russian Monarchy, 2 vols. (Princeton, N.J.: Princeton University Press, 1995-2000). Wortman's work echoes that of Alain Boureau, who has offered a pointed critique of the approach adopted by E.H. Kantorowicz and his school. See Alain Boureau, Le simple corps du roi: l'impossible sacralité des souverains français, $\mathrm{XV}^{e}$-XVIII siècles (P.: Éditions de Paris, 1988); and idem, Kantorowicz: Stories of a Historian, translated by Stephen G. Nichols and Gabrielle M. Spiegel; foreword by Martin Jay (Baltimore: Johns Hopkins University Press, 2001).

2. For recent examples, see Russell E. Martin, “Choreographing the 'Tsar's Happy Occasion': Tradition, Change, and Dynastic Legitimacy in the Weddings of Tsar Mikhail Romanov," Slavic Review 63, 4 (Winter 2004): 794-817; O.G. Ageeva, Evropeizatsiia russkogo dvora, 1700-1796 gg. (M.: In-t rossiiskoi istorii RAN, 2006), esp. 125-130; 147-149; 158-161; and, for a somewhat later period, Mikhail Dolbilov, "The Political Mythology of Autocracy: Scenarios of Power and the Role of the Autocrat," Kritika: Explorations in Russian and Eurasian History, 2, 4 (Fall 2001), 773-795; and idem, "Rozhdenie imperatorskikh reshenii: monarch, sovetnik, i 'vysochaishaia volia' v Rossii XIX v.," Istoricheskie zapiski 9 (2006): 5-48.

3. On the Russian honors system, see A.L. Khazin, Stanovlenie nagradnoi sistemy Rossii $v$ kontse XVII -XVIII vv. Avtoreferat dis. kand. ist. nauk (M., 2008); and V.A. Durov, Russkie nagrady: -nachala XX v. (M.: Prosveshchenie, 1997). On the Order of St. Catherine, see Gary Marker, "Peter the Great's Female Knights of Liberation: The Order of St. Catherine of Alexandria," in Roger Bartlett, Lindsey Hughes, eds., Russian Society and Culture and the Long Eighteenth Century: Essays in Honour of Anthony G. Cross (Münster: Lit, 2004), 35-47; idem, Imperial Saint: the Cult of St. Catherine and the Dawn of Female Rule in Russia (DeKalb: Northern Illinois University Press, 2007), esp. 126-131.

4. James Cracraft, The Petrine Revolution in Russian Culture (Cambridge, MA: The Belknap Press of Harvard University Press, 2004); E.V. Anisimov, The Reforms of Peter the Great: Progress Through Coercion (Armonk, NY: M.E. Sharpe, 1993).

5. M.M. Krom, ed., Novaia politicheskaia istoriia: sbornik nauchnykh rabot (SPb.: Evropeiskii universitet v Sankt-Peterburge, 2004); O.V. Bol'shakova, "Novaia politicheskaia istoriia Rossii: sovremennaia zarubezhnaia istoriografiia," Istoriia Rossii. Seriia analiticheskikh obzorov i sbornikov, 1 (2006): 1-98; and her "Puteshestvie vo vremeni: kul'tura imperatorskoi Rossii v sovremennoi angloiazychnoi istoriografii (obzor)," Istoriia Rossii. Seriia analiticheskikh obzorov i sbornikov 2 (2010): 115-137.

6. Marker, Imperial Saint; Lindsey Hughes, "Catherine I of Russia, Consort to Peter the Great," in Clarissa Campbell Orr, ed., Queenship in Europe, 1660-1815: The Role of the Consort (Cambridge, 2004), 131-154; Iu.M. Popov, "Naimenovaniia korablei russkogo flota, sviazannye s obrazom Ekateriny I," in G.V. Vilinbakhov, et. al., eds., Petrovskoe vremia $v$ litsakh: kratkoe soderzhanie dokladov nauchnoi konferentsii (sPb., 2000), 46-50; and A. Nemshilova, "Venchanie na tsarstvo Ekateriny I: o vozniknovenii i evoliutsii russkikh koronatsionnykh izdanii," Biblioteka 10 (2002): 90-92. For the text of the coronation 
manifesto, see N.A. Voskresenskii, Zakonodatel'nye akty Petra I (M.-L.: Izdatel'stvo Akademii Nauk SSSR, 1945), I, p. 180.

7. On the "affair of the tsarevich, 1715-1717," see Paul Bushkovitch, Peter the Great: The Struggle for Power, 1671-1725 (Cambridge - New York: Cambridge University Press, 2001), ch. 9.

8. Marker, Imperial Saint, 133.

9. As we know, of all the decrees and laws issued during Peter's reign, no less than half were either written by the tsar personally, or shaped decisively by his resolutions. For example, Peter's "Military Regulation" (Ustav voinskii) contains two hundred corrections and additions in the tsar's own hand. Anisimov, The Reforms of Peter the Great, 149, 165; Voskresenskii, Zakonodatel'nye akty Petra I, 294-308, 415-510. For Peter's personal participation in drafting of the Table of Ranks, see S.M. Troitskii, Russkii absol'utizm $i$ dvoriantstvo v XVIII veke: Formirovanie burokratii (M., 1974), 48-104.

10. In addition to the abovementioned works, see L. Hughes, "A Note on the Children of Peter the Great," Study Group on Eighteenth Century Russia Newsletter, 21 (1993): 10-16; V.I. Buganov, "Ekaterina I: [Istoricheskii portret imperatritsy, 1684-1727]," Voprosy istorii 11 (1994): 39-49; A. Kizevetter, "Ekaterina I: Biograficheskii ocherk," in his Istoricheskie siluety (Rostov-na-Donu: Feniks, 1997), 45-61; Astrid Blome, "Schön und weise, klug und löblich. Katharina I. - eine Dienstmagd auf dem Zarenthron," in Karsten Brüggemann, Thomas M. Bohn, Konrad Maier, eds., Kollektivität und Individualität. Der Mensch im östlichen Europa. Festschrift für Prof. Dr. Norbert Angermann zum 65. Geburtstag [= Studien zur Geschichtsforschung der Neuzeit, Band 23] (Hamburg, 2001), 184-211; Igor' Kurukin, "Prevratnosti Fortuny, ili Kartiny iz zhizni Ekateriny I," Znanie-Sila 4 (2002): 112-120; N.I. Pavlenko, Ekaterina I [Zhizn' zamechatel'nykh liudei; vyp. 1104 = 904] (M., 2004); and E.V. Anisimov, "The Cinderella from Livland," in Five Empresses: Court Life in Eighteenth-Century Russia (Westport, CT: Praeger, 2004), 1-54.

11. On Kurakin, see V.I. Semevskii's introduction in M.I. Semevskii, ed., Arkhiv kn. F.A. Kurakina [hereafter Arkhiv], 10 vols. (SPb.: Tip. V.S. Balasheva, 1890-1902), I, p. XX-XXVIII; N. Ch[echulin], "Kurakin, Boris Ivanovich," in Russkii biograficheskii slovar' (SPb.: Tip. Glav. Uprav. Udelov, 1903), 9, p. 572-579; S.I. Kedrov, “Rus' Petra Velikogo za granitseiu: kniaz' Boris Ivanovich Kurakin (Na osnovanii izdannykh knig "Arkhiva kn. F.A. Kurakina")," Russkii arkhiv 2, 5-6 (1903): 23-50; ibid. 3, 11-12 (1903): 353-391; ibid., 2, 5-6 (1904): 174-199; ibid., 1, 3 (1905): 377-424; ibid., 4 (1906): 497-592; ibid., 7 (1907): 289-313; ibid., 2,5 (1912): 5-29; Iu.V. Trifankova, B.I. Kurakin: lichnost' i diplomaticheskaia deiatel'nost': diss. kand. ist. nauk (Riazan', 2007); and Ernest A. Zitser, "The Vita of Prince Boris Ivanovich 'Korybut'Kurakin: Personal Life-Writing and Aristocratic Self-Fashioning at the Court of Peter the Great," Jahrbücher für Geschichte Osteuropas 59, 2 (2011): 163-194. Prince Kurakin and the tsar had both been married to the Lopukhin sisters; until, that is, the end of the seventeenth-century, when Kurakin buried Ksen'ia (1678-1699) in the Chudov Monastery in Moscow and Peter confined Evdokiia (1669-1731) in a convent in distant Suzdal', effectively divorcing her and withdrawing his favor from those members of the Muscovite elite, like Kurakin, who had belonged to the court clique that had arranged his first marriage and had put him on the throne.

12. OPI GIM (Otdel pis'mennykh istochnikov Gosudarstvennogo istoricheskogo muzeia Manuscript Division of the State Historical Museum), f. 3 (Kurakiny), opis' S[taraia], d. 67.

13. For more on Arkhiv kn. F.A. Kurakina, and the reasons why it remains incomplete and difficult to use, see Kedrov, "Rus' Petra Velikogo za granitseiu...," Russkii arkhiv 2, 5-6 
(1903): 25-50, here 26-7n.; and P.A. Druzhinin, "Sud'ba arkhiva kniazia A.B. Kurakina," in P.A. Druzhinin, ed., Neizvestnye pis'ma russkiskh pisatelei kniaziu Aleksandru Borisovichu Kurakinu (1752-1818) (M.: “Truten”', 2002), 77-91, here 78.

14. The first draft has a countermark right under the coat of arms, while the other has it on separate pages (i.e. the coat of arms and the Latin letters are on alternating pages). For an example of a similar watermark, see W.A. Churchill, Watermarks in Paper in Holland, England, France, etc. in the XVII and XVIII Centuries and Their Interconnection (Amsterdam, 1967), 68, Plate XXXVIIII (no. 59) and Plate XXVII (No. 41).

15. OPI GIM, f. 3, op. S, d. 67, 1. 229-235 ob.

16. Ibid., 1. 236-242 ob.

17. Ibid., 1. 174-179 ob.

18. The two chancellery employees were most likely Kurakin's secretary, Fedor Pavlovich Veselovskii (1690-1754), and the clerk (pod'iachii) and "letter-writer" (pis'movoditel') Petr Rogov, both of whom had earlier accompanied the diplomat on his missions abroad and were responsible for providing accurate, literal translations from French and German. Russkii arkhiv 1, 3 (1905): 383, 407, 420; ibid., 4 (1906): 533. One of F.P. Veselovskii's brothers, Avraam (1685-1782/83), had also worked as a translator for Kurakin, before moving on to a position in Menshikov's Izhorsk Chancellery. Another brother, Iaakov (d. 1719), served as a translator and secretary to Menshikov. See D.O. Serov, Stroiteli Imperii: ocherki gosudarstvennoi i kriminal'noi deiatel'nosti spodvizhnikov Petra I (Novosibirsk: Izd-vo Novosibirskogo universiteta, 1996).

19. For a description of Catherine's sixteen-point "manifesto," see T.A. Bykova et. al., ed., Opisanie izdanii, napechatannykh pri Petre Pervom. Svodnyi catalog. Dopolneniia i prilozheniia (L.: Izd. Otdel BAN SSSR, 1972), 17-18 (no.14).

20. The 1714 Statutes were first republished in N.N. Bantysh-Kamenskii's (1737-1814) pioneering survey of Russian imperial orders of chivalry, Istoricheskoe sobranie spiskov kavaleram chetyrekh rossiiskikh imperatorskikh ordenov (M., 1814), which as P.A. Druzhinin has demonstrated, is still incorrectly attributed to D.N. Bantysh-Kamenskii (1778-1850), the son of the long-time archivist of the Moscow Archive of Foreign Affairs. See P.A. Druzhinin, "Istoriia napisaniia i izdaniia knigi 'Istoricheskoe sobranie spiskov kavaleram chetyrekh rossiiskikh ordenov," in P.A. Druzhinin, ed., N.N. Bantysh-Kamenskii, Spiski kavaleram Rossiiskikh imperatorskikh ordenov Sv. Andreia Pervozvannogo, Sv. Ekateriny, Sv. Aleksandra Nevskogo i Sv. Anny s ikh uchrezhdeniia do ustanovleniia $v 1797$ godu ordenskogo kapitula (M.: Izd-vo "Truten"'; Izd-vo "Drevlekhranilishche," 2006), 5-55. The introduction to Bantysh-Kamenskii's publication of the Statutes cited a contemporary description of the 1714 ceremony from "the protokol'naia kniga of Prince Kurakin, the former Russian ambassador to the United Provinces." See Istoricheskoe sobranie>, 133 n.1. In another publication, Bantysh-Kamenskii noted that the "inauguration" (uchrezhdenie) of the Order of St. Catherine/Deliverance was mentioned in Kurakin's protokol'naia kniga under both 1712 and 1713. N.N. Bantysh-Kamenskii, Obzor vneshnikh snoshenii Rossii, po 1800 god. Chast' pervaia: Avstriia, Angliia, Vengriia, Gollandiia, Daniia, Ispaniia (M., 1894), 195 n.1. However, what he called the "1712 book" was in fact a book that covered the period from October 1712 to October 1713, and that included information for August 1713, when the statute was sent to Catherine. The first of the protocol books cited by BantyshKamenskii contains a copy of the statute itself (on the day it was dispatched to Catherine); the second, her letter thanking Kurakin and promising him the blue ribbon of St. Andrew. For the two protocol books in question, see Rossiiskii Gosudarstvennyi 
arkhiv drevnikh aktov (hereafter, RGADA), f. 50 (Snosheniia Rossii s Gollandiei), op. 1, 1712, no. 13 (Kniga, soderzhashchaia $v$ sebe protokoly...); 1713, no. 7 (Kniga, soderzhashchaia $v$ sebe protokoly...). We have not been able to locate the book containing the description of the inauguration of the order. Chronologically, it should have been entered in the 1713 book, which covers the period from October 18, 1713 to May 13, 1715. Yet, in November 1714 Kurakin goes on a mission to London, and his book becomes very sketchy in its coverage. 21. Polnoe sobranie zakonov Rossiiskoi imperii 5, (1830), 129-133 (no. 2860). In addition to the Statutes themselves, the editors of PSZ reprinted the contemporary description of the ceremony cited by Bantysh-Kamenskii, in the process removing the archivist's original reference to the fact that it came from the protokol'naia kniga kept during Kurakin's term as envoy to The Hague. They also noted that "it is not clear from other [legislative] acts when this Statute was confirmed," thereby erroneously assuming that it had indeed been confirmed during Peter's reign. Ibid., 133n.

22. RGADA, f. 50, op. 1, 1712, №13.

23. Kurakin to Count G.I. Golokvin (25 August 1713), Arkhiv, 9: 93-99, here 98.

24. Golovkin to Kurkain (30 Sept. 1713), Arkhiv, 9: 156-158, here 158.

25. Prince B.I. Kurakin to Tsaritsa Ekaterina I (21 August 1713), Arkhiv, 9: 89-90.

26. D'Arcy Jonathan Dacre Boulton, The Knights of the Crown: The Monarchical Orders of Knighthood in Later Medieval Europe, 1325-1520 (Woodbridge, Rochester, NY: Boydell, 2000); and Antti Matikkala, The Orders of Knighthood and the Formation of the British Honours System, 1660-1760 (Woodbridge, Rochester, NY: Boydell Press, 2008).

27. According to Boulton there were, indeed, at least two historically-documented orders devoted to St. Catherine. The first was the "honorific pseudo-order" of the "knights of St. Catherine of Mount Sinai," which "consisted of nothing more than a badge or title borne by those who received them, and served merely to honour their recipient." The second was the "princely confraternal" Order of St. Catherine, which was "founded in the Dauphiné of Viennois at some time between 1330 and 1340" and, like other orders of this type, was intimately "associated with the court or dynasty" of its founder. Boulton, The Knights of the Crown, xix, xix n. 31; and xvi, 45, 177, 27.

28. For example, see the entry accompanying plate XXI: "Eques S. Catherinae/Cavaliere di S. Caterina" in Filippo Buonanni, Catalogo degli ordini equestri, e militari: esposto in imagini, e con breve racconto, offerto alla santita' di n.s. Clemente XI (In Roma: Nella stamperia di Georgio Placco, CDCCXI [i.e. 1711]); and Voyages en Anglois et en François D'A De La Motraye ... (La Haye: Imprime Pour L'Auteur, MDCCXXXII [i.e. 1732]), 72.

29. This quote is from a historical survey of knightly orders in Elias Ashmole, The History of the Most Noble Order of the Garter... (London, 1715 [1672]), 28.

30. Adriaan Schoonebeeck, Histoire de tous les ordres militaires ou de chevalerie de l'un \& de l'autre sexe; ou l'on voit le temps de leur fondation, la vie en abregé, de leurs fondateurs, \& les figures de leurs habits, gravez par Adrien Schoonebeek, divisée en deux tomes (Amsterdam: Chez Adrien Schoonebeek, [ca. 1688]). The second volume of this work was entitled Courte description des ordres des femmes \& filles religieuses. Contenant une petite relation de leur origine, de leur progrés, \& de leur confirmation. Avec les figures de leurs habits.... The 1699 edition of Schoonebeeck's Histoire, which we consulted, was dedicated to the Russian tsar: «Au Tres-Illustre, Tres-Puissant et Tres-Invincible Empereur Pierre Alexewits, Par la Grace de Dieu Grand Prince <...> Se present ouvrage des Ordres Militaires de la Chretienté 
est présenté avec toute sorte de respect et de soumission à Sa Mageste par Son TrèsHumble, Très obeïssant \& Très-dévoüé Serviteur Adrien Schoonebek.»

31. James Cracraft, The Petrine Revolution in Russian Imagery (Chicago: University of Chicago Press, 1997), 120, 165-167.

32. Istoriia o ordinakh ili chinakh voinskikh pache zhe kavalerskikh obderzhashchaia Ustavleniia povedeniia i praktiku, printsipal'nykh deistv, i velikomagisterskikh, so oruzhiem, $i$ ikh figurami. ... napechatana poveleniem tsarskogo velichestva $v$ tipografii moskovskoi leta Gospodnia 1710-go v mesiat Avgust (M.: Moskovskaia tipografiia, 1710), which constitutes a translation of only the first part of 1699 French original, i.e. it completely omits Schoonebeek's discussion of female orders. On Schoonebeek and the anonymous Russian translation, see P.P. Pekarskii, Nauka $i$ literatura $v$ Rossii pri Petre Velikom, 2 vols. (SPb.: «Obshchestvennaia pol'za», 1862), 2, 244-247.

33. Schoonebeck devotes only one page to a discussion of "Les Chevaliers de Ste. Caterine du Mont-Sinai et du Jerusalem," see ibid. 158.

34. Schoonebeck, ibid., noted that «On ne trouve point que cet Ordre ait été confirmé par aucun Pape; mais on sait qu'il a été entiérement anéanti par la retraite quels Princes Chrétiens ons été obligez de faire de la Terre Sainte devant les Forces des Turcs.» This may have been the technicality that allowed Kurakin to claim that the Russian monarch was merely "reviving this order in Europe."

35. Boulton, The Knights of the Crown, 500; for an in-depth treatment of the "restoration and revival" of the Order of the Garter, see Matikkala, The Orders of Knighthood, 62-88.

36. Boulton, The Knights of the Crown, 499-500, 500n.10: St. Louis, France, 1693; The Elephant, Denmark (1457), statutes 1693; The Dannebrog, Denmark (1671), statutes 1693; St. Michael, Bavaria, 1693; St. Andrew, Russia, 1698; The Black Eagle, Prussia, 1701; The Hunt, Wurtemberg, 1702; The Thistle, Scotland (revived again) 1703; Sincerity (or the Red Eagle), Prussia, 1705, 1712; St. Hubert, Bavaria, (revived) 1708; The White Eagle, Poland, 1713; Fidelity, Baden, 1715.

37. On the order of St. Andrew, see G.V. Vilinbakhov, "K istorii uchrezhdeniia ordena Andreiia Pervozvannogo i evoliutsii ego znaka," in Kul'tura $i$ iskusstvo petrovskogo vremeni: publikatsii $i$ issledovaniia (L., 1977), 144-158; A.L. Khazin, "Vysshaia nagrada otechestva: $\mathrm{k}$ voprosu o sozdanii statuta ordena Sviatogo apostola Andreia Pervozvannogo," Voenno-istoricheskii arkhiv 12 (2008): 53-5. Matikkala, The Orders of Knighthood, 241-242, suggests that it, too, may have been instituted in order to raise the prestige of the saint to whom it was dedicated, since previous orders bearing the name of St. Andrew, including the Thistle, had "lapsed." She also points out that Schoonebeek's decision to begin his book on orders of chivalry with a discussion of the legendary order of St. Constantine bolsters Vilinbakhov's argument about the "Constantinian" source of the Russian Order of St. Andrew.

38. According to evidence cited by Pekarskii, Nauka i literature v Rossii, I, 90-91, 106, around 1717 Peter charged Baron Heinrich von Huyssen with writing up a draft of the statutes (ustavil stat'i) for the Order of St. Andrew that included extensive commentary in the margins on other contemporary monarchical orders. This may be the very document published by D.G. Fedosov, "K trekhstoletiiu pervogo Rossiiskogo ordena," Srednie veka 62 (2001): 247-274.

39. Buonanni's Catalogo degli ordini equestri, e military, for example, included an “Appendix: Continens Foeminas ad Equestres Ordines Spectantes \& Infideles." 
40. Buonanni, Catalogo degli ordini equestri, Plate CXXVII [i.e. 127], depicting "Moniales [i.e. nuns] B. Mariae de Mercede Redemptionis captivorum/Monache di S. Maria della Mercede della Redenzione delli Schiavi."

41. For a discussion of the trope of "divining the monarch's will" (ugadyvanie tsarskoi voli), and its use by state functionaries as a stratagem for influencing royal decisionmaking, see Dolbilov, "Rozhdenie imperatorskikh reshenii," 9, 16-24.

42. Buonanni, Catalogo degli ordini equestri, Plate CXXXI [i.e. 131]: Ordo Foeminarum que Familae virtutis dieuntur/Ordine delle schiave della Virtu." For the statutes of the order and a list of its members, see Johann David Köhler, "Das goldene Schaustück des von der verwittibten Röm. Kayserin Eleonora A. 1662 gestiffteten Damenordens der Sclavinnen der Tugend," Historische Münzbelustigung, 21 (1749): 169-176.

43. Sabine Koloch, "Neue Befunde zu dem habsburgischen Damenorden 'Sklavinnen der Tugend," Orden und Ehrenzeichen. Das Magazin für Sammler und Forscher (= BDOS-Jahrbuch 1999): 29-31; Katrin Keller, Hofdamen: Amtsträgerinnen im Wiener Hofstaat des 17. Jahrhunderts (Wien: Böhlau, 2005), 173; eadem, "Frauen und Politik in der höfischen Gesellschaft des Alten Reiches zwischen 1550 und 1750," Zeitenblicke 8, Nr. 2, [30.06.2009]: 1-30, here 14-5. URL: http://www.zeitenblicke.de/2009/2/keller/index_html.

44. Koloch, "Neue Befunde zu dem habsburgischen Damenorden," 30-31. See also Hermann Dikowitsch, "Die Österreichischen Damenorden," in Johann Stolzer, Christian Steeb, eds., Österreichs Orden vom Mittelalter biz zur Gegenwart, ed. (Graz, 1996), 183-196, esp. 183-188.

45. Habsburg piety was centered around the veneration of the Eucharist, the Virgin Mary, the Catholic saints, and the Cross of Christ (fiducia in crucem Christi). See Anna Coreth, Pietas Austriaca. Translated by William D. Bowman and Anna Maria Leitgeb [Central European studies series] (West Lafayette, IN : Purdue University Press, 2004).

46. Ibid., 40-42; and Charles W. Ingrao, Andrew L. Thomas, "Piety and Power: The Empresses-Consort of the High Baroque," in Cambpell Orr, ed., Queenship in Europe, 1660-1815, 107-130, here 120.

47. Documents associated with the foundation of this order (including its statutes [Satzungen] and the letters of confirmation [Bestätigungsschreiben] from Emperor Leopold I and Philipp Friederich, Bishop of Vienna) were included into the prayer book of the order, which was written in Italian by a popular Jesuit preacher named Giovanni Battista Manni (1606-1682), and translated into both German and French. See Tres noble et Pieuse assemblée de l'ordre de la Croix étoilee, instituée par l'impératrice Eléonore pour la dévotion du Saxe Noble and Hoch-Adeliche und Gottseelige Versammlung von Stern-Creutz genannt So von Ihro Kayserlichen Majestät Eleonora verwittibten römischen Kayserin auffgerichtet: und estlich zwar Ihro Königl: Majestät Eleonorae regierenden Königin in Pohlen. Ertz-Hertzogin von Oesterreich (Wienn: gedruckt bey Leopold Johann Kaliwoda ..., 1697). We consulted an 1839 republication of the German text published in Vienna: Hochadelige und gottselige Versammlung vom Sternkreuze (Wien, 1839).

48. Gottseelige Versammlung von Stern-Creutz genannt, 160-164. See also Hermann Dikowitsch, "Die Österreichischen Damenorden," in Stolzer, Steeb, eds., Österreichs Orden vom Mittelalter, 183-196, here 183-189.

49. Coreth, Pietas Austriaca, 41; Ingrao, Thomas, "Piety and Power," in Cambpell Orr, ed., Queenship in Europe, 1660-1815, 107-130, here 120. 
50. L.A. Markina, "Sofiia Sharlotta Braunshveigskaia-pervaia nemetskaia printsessa v Rossii," in Nemtsy $v$ Rossii: problemy kulturnogo vzaimodeistviia, otv. red. L.V. Slavgorodskaia (SPb.: DB, 1998), 41-52; and S.R. Dolgova, "Brachnyi soiuz tsarevicha Alekseia i vol'fenbiutel'skoi printsessy Sharlotty," in Nemtsy Sankt-Peterburga: nauka, kul'tura, obrazovanie, otv. red. Galina Smagina [Dialog dvukh kul'tur] (SPb.: Rostok, 2005), $55-66$.

51. Gottseelige Versammlung von Stern-Creutz genannt, 161; Dikowitsch, "Die Österreichischen Damenorden," in Stolzer, Steeb, eds., Österreichs Orden vom Mittelalter, 187.

52. Kedrov, Russkii arkhiv 1, 3 (1905): 413-414, 419.

53. The fact that by means of this match Kurakin became related by marriage to both the Romanov and Habsburg dynasties did not appear to have erased the "affront" that he experienced as a result of the tsar's decision to seat his former brother-in-law "in last place." Kurakin may also have resented the fact that Prince V.V. Dolgorukov, the courtier whom he identified as his personal "enemy," received the Order of St. Andrew, alongside Tsarevich Aleksei and the father-of-the-bride, while he (the Tsarevich's own uncle) was passed over. "Zapiski kniazia Borisa Ivanovicha Kurakina o prebyvanii v Anglii, ot"ezde v Rossiiu k armii, puteshestvie s tsarem Petrom Alekseevichem v Karlsbad i o naznachenii svoem na s"ezd v Utrekht, 1710-1711-1712. Pisano v aprele 1712 g." in Arkhiv, 3: 310-11; and Kedrov, Russkii arkhiv, 7 (1907): 311-312. On Dolgorukii's award, see Bantysh-Kamenskii, Spiski, 66.

54. Kurakin to Count G.I. Golokvin (25 August 1713), Arkhiv, 9: 93-99, here 98.

55. Durov, Russkie nagrady, 20.

56. Tsarista Ekaterina Alekseevna to Prince B.I. Kurakin (30 September 1713), Arkhiv, 2: 270.

57. We must remember that for much of the early modern period, official correspondence in general, and royal letter-writing in particular was not a private act. It was, rather a semi-public, performative moment, which provided yet another opportunity to project a particular scenario of power, and involved not only the addressee, but also the scribe to whom it was dictated and the one who might have first opened the letter upon receipt. An example of this is the note that Kurakin's secretaries made about Catherine's letter: “This [letter] from the sovereign tsaritsa to Prince Boris Ivanovich Kurakin, [to the effect] that the recently mailed order called Deliverance (ordin nazyvaemyi Svobozhdeniia) was received and that by a decree of His Tsarist Majesty it was announced (ukazom tsarskogo velichestva ob"iavleno) that the abovementioned Prince was to be given a blue sash for his labors in this matter ( $z a$ onyi trud), arrived in The Hague on 13 November 1713." Arkhiv, 2: 270.

58. At the end of June 1709, just a few days before the battle of Poltava, the tsar had publicly berated Kurakin for "seeking the chance to become a foreign ambassador" instead of "serving in the military"; threatened him with the gallows, should he "not perform [his] duty during the occasion of the [much anticipated] battle with the enemy"; and then, after the conclusion of Russia's decisive victory, deliberately passed him over for promotion, while generously handing out "ranks, medals, crosses, and chivalrous orders (kavalerii)" to all and sundry. This particular entry of the Prince's autobiographical Vita was written sometime after 20 July 1710. Zitser, "The Vita of Prince Boris Ivanovich 'Korybut'- Kurakin,” 178-179. 
59. In 1712, for example, Kurakin made a special effort to record the Polish ambassador's promise to award him the Order of the White Eagle. See Arkhiv, 5: 123 As early as 1711, Kurakin had posed for a three-quarter-length portrait by Sir Godfrey Kneller, the German-born, British painter who specialized in "Garter portraits," i.e. Baroque parade portraits of Knights of the Order of the Garter. In 1717, Kneller's portrait of Kurakin would be used by Pieter Stevens van Gunst as the basis for an engraved oval portrait that depicted the Russian ambassador with the sash and cross of the Order of St. Andrew. See Cracraft, The Petrine Revolution in Russian Imagery, 194-195, 340 n.92.; and V.F. Vasilenko, "Neizvestnyi portret kniazia Borisa Ivanovicha Kurakina," in Kurakinskie chteniia, ed. Dzh. B. Logashova (M.: GU MDN, 2006), 142-66. On Kneller and the "Garter portraits," see Matikkala, The Orders of Knighthood, 232-230; it should be noted, however, that Kneller's portrait of Kurakin is not listed in the artist's catalog of paintings and drawings. See J. Douglas Stewart, Sir Godfrey Kneller and the English Baroque Portrait [Oxford studies in the history of art and architecture] (Oxford: Clarendon Press; New York: Oxford University Press, 1983).

60. Prince B.I. Kurakin to Tsaritsa Ekaterina I (27 November 1713), Arkhiv, 9: 218.

61. There is some confusion about the exact date of Kurakin's induction into the Order. According to Bantysh-Kamenskii, Kurakin received the order of St. Andrew "personally from the hands of Peter the Great" on 28 March 1717 (18 March, according to the entry in Russikii biograficheskii slovar'), i.e. immediately upon Peter's arrival in Holland, just prior to the Emperor's trip to France. D.N. Bantysh-Kamenskii, "Biografiia kniazia Borisa Ivanovicha Kurakina," in Deianiia znamenitykh polkovodtsev i ministrov Petra Velikago 2 vols. (M., 1813), 2: 37-54, reprinted in Arkhiv, 7: 415-421, here 419; RBS (1903), 9: 576. However, according to the inscription on Kurakin's own tombstone, he received the Order after visiting France, in the "Prussian town of Cleves" (Prusskom gorode Kleve), which the tsar's suite passed sometime between 13-22 July. It is, of course, possible that Kurakin was inducted in March 1717 but did not actually receive the badge until July of that year. T.D. Panova, Nekropoli Moskovskogo Kremlia, 2-e izd., ispr. i dop. (M.: 2003), 54-55, here 55. For the tsar's itinerary on the way back from France, see PZh,1717, 29-30.

62. The award ceremony took place after the conclusion of the regular service, in the newly-built church named for St. Isaac of Dalmatia, the tsar's birthday saint. BantyshKamenskii, Istoricheskoe sobranie spisok kavaleram, 135; PSZh 1714, 79.

63. While it is well known that Kurakin regularly carried out commissions and purchased items requested by Peter, little is known about the scope of his activity on behalf of the tsar's official consort. Judging by the published correspondence, their working relationship began at the end of April 1711, in connection with Catherine's request for a set of foreign-made, portrait miniatures of the tsar. See Baron P.P. Shafirov to Prince B.I. Kurakin (29 April 1711) in Arkhiv, 2: 355; B.V. Olad'in to Prince B.I. Kurakin (24 August/5 September 1711), ibid., 5: 167; B.V. Olad'in to Prince B.I. Kurakin (11/22 September 1711), ibid., 5: 167-169; and Count G.I. Golovkin to Prince B.I. Kurakin (29 November 1711), ibid., 5: 177-178. Afterwards, Catherine inaugurated a direct personal correspondence with Kurakin, primarily about the acquisition of luxury consumer items from abroad, both for herself and for her children with Peter. For example, see Prince B.I. Kurakin to Tsaritsa Ekaterina I (24 July 1713), Arkhiv, 9: 58-9.

64. RGADA, f. 9 (Peter I's Cabinet), Otdelenie II, kniga 20, 1. 577.

65. Arkhiv, 6: 42-43. 
66. Arkhiv, 6: 42-43.

67. Linda Frey, Marsha Frey, eds., The Treaties of the War of the Spanish Succession: An Historical and Critical Dictionary, (Westport, CT., 1995), 139. The only extended biographical study remains Georg Friedrich de Martens, "Recherches sur la vie et escrits de Jean Dumont, Baron de Carlscroon, redacteur du Corps universel diplomatique du droit des gens," in Supplément au Recueil de principaux traités d'alliance, de paix, de trêve ... : précédé de Traités du XVIIIème siècle antérieurs a cette époque et qui ne se trouvent pas dans le Corps Universel Diplomatique de mrs. Dumont et Rousset ..., 4 vols. (Gottinguen: Dieterich, 1802-1807), I: LXXIV-XCIV, esp. LXXVI (on the prefered spelling of his name).

68. Jean Dumont, ed., Corps universel diplomatique du droit des gens; contenant un recueil des traitez d'alliance, de paix... de toutes les conventions... \& autres contrats, qui ont été faits en Europe, depuis le regne de l'empereur Charlemagne jusques à présent; avec les capitulations imperiales et royales... \& en général de tous les titres... qui peuvent servir à fonder, établir, ou justifier les droits et les interets des princes et etats de l'Europe..., 8 vols. (Amsterdam: Chez P. Brunel, $R$ et $G$. Wetstein, les Janssons Waesberge, et L'Honoré et Chatelain; La Haye: Chez P. Husson et Charles Levier, 1726-1731).

69. Ibid., vol. 8, Part 1: 275-276. The draft in question was the heavily-revised version intended for distribution abroad; it was personally edited by Peter and "given to the Dutch government" by none other than "the Russian ambassador" (most likely A.A. Matveev, Kurakin's predecessor on the job). For a discussion of the different redactions of the Pruth peace treaty, see Ia.E. Vodarskii, Zagadki Prutskogo pokhoda Petra I I (M.: Nauka, 2004), 162-167, here 166-167, 202 n.48.

70. This interpretation is bolstered by the fact that Du Mont's erstwhile collaborator and continuator of the Corps universel was none other than Jean Rousset de Missy (1686-1762), a.k.a. "Ivan Nestesuranoi," who authored the histories of Peter I and, later, of Catherine I, both of which were highly favorable towards these Russian monarchs. According to N.A. Kopanev, Kurakin played a key role in commissioning the book on Peter and might have even written the introduction. Iwan Iwanowitz Nestesuranoi [Jean Rousset de Missy], Memoires du regne de Pierre le Grand, empereur de Russie, Père de la patrie, \&c.\&c.\&c (La Haye: Chez R.C. Alberts; Amsterdam: Chez Her. Uytwerf, 1725-1726); idem, Memoires du regne de Catherine imperatrice \& souveraine de toute la Russie. \&c. \&c. \&c. (La Haye: Chez Alberts \& Vander Kloot, 1728); and N.A. Kopanev, “Kniaz' B.I. Kurakin i russkaia istoriografiia,” in Russkoe prosvetitel'stvo kontsa XVII -XVIII vekov v kontekste evropeiskoi kul'tury: tezisy dokladov nauchnoi konferentsii (SPb.: Gos. Ermitazh, 1997), 25-29, esp. 27-28. On de Missy, see also S.A. Mezin, "Petr I vo frantsuzskoi istoriografii XVIII veka," Rossiia i Frantsiia XVIII -XX veka, 3 (2000), 14-36, here 14-21 ; and G. Shatokhina, "Gollandskii publitsist Zhan Russe de Missi i ego sviazi s Rossiei," in Emmanuel Waegemans, ed., Russia and the Low Countries in the Eighteenth Century [Baltic Studies, 5], (Groningen, 1998), 111-123.

71. For an analysis of this discourse, see Elena Pogosian and Mariia SmorzhevskikhSmirnova, “Tsar' Petr Alekseevich i Gosudarynia Ekaterina Alekseevna na ikone Tallinskogo Nikol'skogo khrama," in I. Belobrovtseva, ed., Russkie v Pribaltike: sbornik statei (M.: Nauka, 2010), 21-47; and “'Iako az na rany gotov': Petr I na ikone Tallinskogo Nikol'skogo khrama," in Trudy po russkoi i slavianskoi filologii. Literaturovedenie. VII (Novaia seria) (Tartu: Tartu Ülikooli Kirjastus, 2009), 11-37. We are grateful to these scholars for sharing their their work-in-progress before its publication.

72. On the different semantic fields associated with the term for "nobility," see Marc Raeff, "La noblesse et le discours politique sous le règne de Pierre le Grand," Cahiers du 
monde russe et soviétique 34, 1-2 (1993): 33-46; as well as M.A. Kiselev, "'Famil'nye' vs. 'shliakhetstvo': problema samosoznaniia 'dvorianskogo sosloviia' v 1730 g." and N.N. Petrukhintsev, "Konsolidatsiia dvorianskogo sosloviia i problemy formirovaniia oformliaiushchei ego terminologii," papers delivered at the conference on "Praviashchie elity i dvorianstvo Rossii vo vremia i posle petrovskikh reform (1683-1750)," which was held at the German Historical Institute in Moscow, 9-11 June 2011. We are grateful to the organizers of the conference and its participants for sharing these stimulating and soonto-be published articles. On Kurakin's Polonophilia see Zitser, "The Vita of Prince Boris Ivanovich 'Korybut'-Kurakin,” 169-172.

73. T.A. Bazarova, "Vozvrashchenie Karla XII v Shvetsiiu posle Poltavy v russkoi diplomaticheskoi perepiske: po materialam pokhodnoi kantseliarii P.P. Shafirova," in O.G. Ageeva, et al., eds., Poltava: $k$ 300-letiiu Poltavskogo srazheniia: sbornik statei (M.: Kuchkovo pole, 2009), 219-228.

74. OPI GIM, f. 3 (Kurakiny), op. S[taraia], d. 69 (Zapiski del kniazia Borisa Ivanovicha Kurakina, 1712-1713), 1. $167 \mathrm{ob}$.

75. Although they had been married for two years, Charlotte only moved to Russia in April 1713; Aleksei joined her several months later. Dolgova, "Brachnyi soiuz tsarevicha Alekseia," 63-64; Markina, "Sofiia Sharlotta Braunshveigskaia," 45-46.

76. See P.A. Krotov, Gangutskaia bataliia 1714 goda (SPb.: Liki Rossii, 1996), 16-48, esp. 28-29.

77. For an earlier usage, see K. Schaller, “Emendatio omnium' - A pedagogic or a political programme?" in R.R. Bolgar, ed., Classical Influences on Western Thought A.D. 1650-1870, ed. (Cambridge, NY: Cambridge University Press, 1979), 77-92, here 90, 92. On Du Mont's religious affiliation, see de Martens, "Recherches sur la vie et escrits de Jean Dumont," I: LXXXVIII.

78. For a discussion of the concept of "fatherland" in Russian and Ukrainian political cultures of the time, see Frank E. Sysyn, "Fatherland in Early Eighteenth-Century Ukrainian Political Culture" and Serhi Plokhy, "The Two Russias of Teofan Prokopovyc," both in Giovanna Siedina, ed., Mazepa e il suo tempo: storia, cultura, società = Mazepa and his time: history, culture, and society (Alessandria: Ed. Dell'Orso, 2004), 39-53 and 333-366, respectively. Paul Bushkovitch, "Fatherland in Russian Culture (Fifteenth-Seventeenth Centuries)," Journal of Ukrainian Studies (2008-2009): 93-103, has noted that the idea of "fatherland" had appeared in Russian writings even before it was famously invoked by Feofan Prokopovych. Kurakin, for one, had used the term patria to boast about the "honor and glory" that his 1707 mission to Italy had brought both to "the Russian realm" (gosudarstvo rossiiskoe) and to "the fatherland for which my house (i patrii imeni svoego domu), the Caributoff Karakinigh, hereditary Lithuanian princes (kniazei nasledstvennykh litovskikh)" was named. See Zitser, The Vita of Prince Boris Ivanovich 'Koribut'-Kurakin, 172 .

79. The order is mentioned in G.V. Esipov, "Zhizneopisanie kniazia A.D. Menshikova po novootkrytym bumagam," Russkii arkhiv 3, 9 (1875): 47-74, here 74n.65. Although all subsequent biographies of Peter's favorite refer to Esipov's groundbreaking work, as far as we know, none has picked up his discussion of this particular episode. See N.I. Pavlenko, N.I. Pavlenko, Poluderzhavnyi vlastelin: istoricheskaia khronika o zhizni spodvizhnika Petra Pervogo A.D. Menshikova (M., 1991); N.V. Kaliazina and E.A. Kaliazin, Aleksandr Menshikov-stroitel' Rossii, 2 vols. (SPb., 2005-2006); Iu.N. Bespiatykh, Aleksandr Danilovich Menshikov: mify i real'nost' [Biblioteka Fonda pamiati svetleishego kniazia A.D. 
Menshikova] (SPb., 2008). It is not clear, however, whether in this phrase Menshikov acknowleged the receipt of an object (a star), or just of the drawings discussed below.

80. RGADA, f. 198 (Menshikov), op. 1, d. 1170 (Letters of A.D. Menshikov to Daria Menshikova), 1. 154. This undated and unsigned drawing is included between the letters from 31 May and 1 June 1709 (neither of which refers to the order, however).

81. The three sketches of the order are in ibid., 1. 133-135. The ones on l. 133 and 135 are identical to each other; the one on 1.134 includes the addition of four letters ( $\kappa, O, \amalg$, and $S$ ), which were probably supposed to be read in the same order as when crossing oneself and which represented the initials of a phrase we have not been able to decipher.

82. Bushkovitch, "Fatherland in Russian Culture," 100-101, has noted that in the seventeenth century the idea of "fatherland" was used in Russian royal "charter[s] granting estates as a reward for service" (zhalovannye gramoty), thereby allowing "the recipient's descendents to remember their ancestors' service to Orthodoxy, the tsar, and the fatherland." Since Menshikov's awards after the battle of Poltava also included extensive land grants, it is possible that the order's creators were invoking the "documentary formulas of land grants" when they formulated its motto, in effect complementing and acknowledging the royal gift.

83. On the relationship between Catherine and the Menshikovs, see Kaliazina, Aleksandr Menshikov-stroitel' Rossii, I: 203-8; II : 424-35.

84. RGADA, f. 198 (Menshikov), op. 1, d. 1170 (Letters of A.D. Menshikov to Daria Menshikov), l. 91 ob, 116, 117, 150.

85. Pavlenko, Ekaterina, 184: no. 45: Peter to Catherine (2 Dec. 1712): "the time has come for you to pray, and for us to work (vremia prishlo vam molitsa, a nam truditsa)."

86. RGADA, f. 198 (Menshikov), op. 1, d. 1170 (Letters of A.D. Menshikov to Daria Menshikov), 1.126, 130.

87. Like the icon that Menshikov commissioned in 1711, which has been expertly decoded by Pogosian and Smorzhevskikh-Smirnova, "Kak i slovom obiazalsia ia”".

88. Arkhiv, I: 283-5. Kurakin blamed this temporary fall from grace on the intrigues of his "enemies" at court, particularly Prince V.V. Dolgorukii, "who sought to have my head [purely] out of envy, because he saw that Prince Menshikov showed me favor and loved me" (lo quale cercava sine adesso la mia testa per invidia, perche vedendo favori del $P$. Menscikoff, come mi amato). This was the very same individual who was personally entrusted to spearhead a criminal investigation into Menshikov's financial irregularities. Coincidentally, the first arrests made in connection with this case took place on 25 November 1714, the day after Catherine's public induction into the Order. See Bushkovitch, "Peter the Great: The Struggle for Power," 320-325.

89. Kurakin was one of the Russian military men who appended his signature to the collective congratulatory letter addressed to Daria, soon after she had given birth to the Menshikovs first son. RGADA, f. 198, d. 1170, 1. 500, cited in Kaliazina, Aleksandr Menshikov-stroitel' Rossii, 2, 442.

90. At this point we can only speculate on the reasons for Peter's reticence about recognizing the project pushed through by Catherine and her supporters. It may very well be the case that the tsar did not want his hand forced by his advisors, particularly when it came to such a delicate topic as precedence within the royal family and the issue of succession to the throne. For examples of similar sentiments among later royals, see Dolbilov, "Rozhdenie imperatorskikh reshenii," 17, 20. 
91. See Medals and Coins of the Age of Peter the Great from the Hermitage Collection, comp. and introd. by I.G. Spasskii, and E.S. Schukina (L.: Aurora Art Publishers, 1974), 36 (medal in honor of F.A. Golovin, extraordinary ambassador during the "Great Embassy," c. 1698); 37 (medal in honor of Admiral F.M. Apraksin, 1708); 38 (reward medal to Captain Matvei Simontov, for building the harbor of Taganrog, 1709); and the discussion of named commemorative medals in Durov, Russkie nagrady, 36-37.

92. Such as the "Judas medal" (1709), commemorating Hetman I.S. Mazepa's "contribution" to the successful outcome of the battle of Poltava. On the "Order of Judas," see Ernest A. Zitser, The Transfigured Kingdom: Sacred Parody and Charismatic Authority at the Court of Peter the Great (Cornell: Cornell University Press, 2004), ch. 2; and Elena Ukhanova, "Medal' dlia 'Novogo Iudy,"' Rodina 11 (2007), available online at: http://www.istrodina.com/rodina_articul.php3?id=2410\&n=120 (last accessed 12 January 2012).

93. See PSZh 1714, 79.

94. Especially since Catherine was not the only married woman to follow her husband on the Pruth campaign. As Vodarskii reminds us, the wives (and children) of foreign officers also went along with them. See Vodarskii, Zagadki Prutskogo pokhoda Petra I, 73. The only individuals to receive a medal for their participation in the unsuccessful campaign of summer 1711 were the Orthodox South Slavic vassals of the Ottoman Porte, who had attempted to organize an uprising to coincide with the Russian incursion into the Balkan peninsula. Durov, Russkie nagrady, 31-33.

95. Vodarskii, Zagadki Prutskogo pokhoda Petra I, 110-113, 177-180.

96. Significantly, this re-interpretation took place after Aleksei's defection abroad. Marker, "Peter the Great's Female Knights of Liberation," 41, singles out two publications from 1717: Feofan Prokopovich's name-day sermon on "St. Catherine the Great Martyr, the Namesake of the Good Sovereign Lady Catherine I, the All-Russian Tsaritsa"; and the "Greeting from the Saint Petersburg Typography to the Great Sovereign, All-Russian Tsaritsa, Most Noble Grand Princess Ekaterina Alekseevna," which praised her "immeasurable manly bravery" (bezmernoe muzhestvo) at the Pruth. Praise for Catherine's "manly rather than lady-like behavior" (muzheski, a ne zhenski postupala) reached its apogee in 1724, during Catherine's coronation as empress.

97. The five enamel stars (kavalerii) that the tsaritsa commissioned from Kurakin in 1718 might serve as another indication of her sustained interest in the Order. If these really were intended as crosses of the Order of St. Catherine, then we have another piece of evidence of Catherine's personal involvement in the creation of her order, even before Peter's death. According to the "Register of the sovereign tsaritsa's money" ("Vedomost' den'gam gosudaryni tsaritsy"), these stars were not only manufactured on Catherine's request and sent to her directly, but were also paid for from her private purse (at the cost of 120 guilders each). To put this order in the context of Catherine's other concerns at the time, we should mention that simultaneously with getting the stars produced, Kurakin was overseeing the engraving of her portrait for printing (and, one might guess, subsequent distribution). RGADA, f. 9 (Peter I's Cabinet), Otdelenie II, kniga 15, 1. 492-495 (Letters of B.I. Kurakin to Catherine).

98. For a list of the Lady Knights of the Order of St. Catherine, see S.S. Levin, Orden sviatogo apostola Andreia Pervozvannogo (1699-1917), Orden sviatoi velikomuchenitsy Ekateriny (1714-1917): spiski kavalerov i kavalerstvennykh dam (M.: Blok, 2003), 52-108, here 52-53. 
99. On the use of this trope, see V.Iu. Matveev, "K istorii vozniknoveniia i razvitiia siuzheta 'Petr I - vysekaiushchii statuiu Rossii," in Kul'tura i iskusstvo Rossii XVIII veka (L., 1981), 26-43.

100. See Cambpell Orr, ed., Queenship in Europe; Koloch, "Neue Befunde zu dem habsburgischen Damenorden"; and Anne Walthall, ed., Servants of the Dynasty: Palace Women in World History [The California world history library, 7] (Berkeley: University of California Press, 2008). For the Russian case, see the previously-cited works of L. Hughes and G. Marker; as well as Isolde Thyrêt, Between God and Tsar: Religious Symbolism and the Royal Women of Muscovite Russia (DeKalb, Ill.: Northern Illinois University Press, 2001); Anisimov, Five Empresses; and O.N. Mukhin, "Zhenshchiny tsarskoi sem'i v epokhu petrovskikh reform: roli i sud'by" in Mir Klio: Sbornik statei $v$ chest' Loriny Petrovny Repinoi (M., 2007), 396-412; idem, "Petr I i 'zhenskii vopros': vlast' i gender v Rossii XVIII veka," Vestnik Tomskogo gosudarstvennogo pedagogicheskogo universiteta. Seriia Gumanitarnye nauki 4, 41 (2004): 5-9.

101. Mikhail Krom, "Formen der Patronage im Russland des 16. und 17. Jahrhunderts: Perspektiven der vergleichenden Forschung im europäischen Kontext," Jahrbücher für Geschichte Osteuropas, 57, 3 (2009): 321-345

102. Zitser, "The Vita of Prince Boris Ivanovich 'Korybut'-Kurakin," 185.

103. RGADA, f. 198 (Menshikov), op. 1, d. 684 (Letters of B.I. and A.B. Kurakins to A.D. Menshikov), 1. 135, 155, 181 ob.

*. OPI GIM, f. 3, op. S, d. 67, 1. 236-242. As reproduced here, underlining is used in the original to indicate quotations and to highlight certain other passages.

*. OPI GIM, f. 3, op. S, d. 67, 1. 174-179 ob. Italics indicate passages inserted on the margins or between the lines in Boris Kurakin's hand. Angular brackets indicate passages crossed out in the original document.

104. Crossed out by Kurakin's assistant.

105. Inserted on the margin and then crossed out by Kurakin's assistant.

106. The version eventually dispatched to Catherine read "ОдНУ ПЕРВЕНСТВУющУю ПЕРСОНУ, ТО ЕСТЬ ГОСПОЖА ОР ДИНУ ИЛИ ПО-НЕМЕЦКИ Gross Meisterin des Ordens" (OPI GIM, f. 3, op. S, d. 69 (Zapiski del kniazia Kurakina, 1712-1713), 1. 167 ob.

107. "Conjugal" is inserted and then crossed out in Boris Kurakin's hand.

108. No such drawings are found.

109. Paragraph 8 was skipped (apparently, unintentionally) by one of the translators and inserted on the margin by the other.

110. The original version of paragraph 13 was crossed out entirely and replaced by a significantly reworded version added at the end of the document (l.179 ob), apparently, in Boris Kurakin's hand. 


\section{RÉSUMÉS}

Résumé

Cet article décrit les origines et la portée politique de l'ordre de Sainte-Catherine ou de la Délivrance, le second ordre de chevalerie du système honorifique russe à avoir été mis en place sous le règne de Pierre le Grand, et le premier ordre monarchique russe à disposer de ses propres statuts et à être exclusivement réservé aux femmes. La fondation de l'ordre de SainteCatherine a traditionnellement été décrite comme un projet mené par le tsar lui-même et reflétant sa vision des choses. Cependant, comme le montrent les documents d'archives dernièrement découverts et analysés dans cet article, le rôle clé de cet épisode revient à la tsarine Catherine et à ses conseillers et clients tandis que le tsar semble n'avoir été, dans le meilleur des cas, qu'un observateur passif. Bien que la politique dynastique de Pierre et son intérêt pour les ordres monarchiques laïques aient sans doute défini le cadre général de ce qu'il était possible de faire, la conception spécifique de ce projet ne reflétait pas tant la volonté du tsar que les idées d'acteurs tels que Catherine, le favori royal (A.D. Menšikov) et l'ex-beau-frère du tsar (y compris le prince B.I. K urakin). La reconstitution des circonstances réelles de la fondation de l'ordre permet ainsi de documenter une étude de cas détaillée $\mathrm{du}$ rôle du clientélisme politique dans la formation des mises en scène du pouvoir aux premières heures de la cour impériale russe.

Abstract

This article describes the origins and political significance of the Order of St. Catherine, or Deliverance: the second-oldest knightly order in the system of honors introduced during the reign of Peter I, the first Russian monarchical order to have its own set of statutes, and the only one reserved exclusively for women. The foundation of the Order of St. Catherine has traditionally been described as a project driven by, and reflecting the vision of the tsar himself. However, as the newly discovered archival documents analyzed in this article indicate, the key role in this episode actually belonged to Tsaritsa Catherine Alekseevna and her advisors and clients, while the tsar seems to have been at best a passive observer. Although Peter's dynastic policy and his interest in lay monarchical orders obviously set the overall framework for what was possible, the specific design of this project reflected not the tsar's will, but the personal agendas of such actors as the royal consort (Catherine), the royal favorite (A.D. Menshikov), and the tsar's former brother-in-law (including Prince B.I. K urakin). A reconstruction of the actual circumstances of the Order's foundation thus provides the evidence for a detailed case study of the role of political clientage in shaping the scenarios of power at the early Imperial Russian court.

\section{AUTEURS}

\section{IGOR FEDYUKIN}

Igor Fedyukin, New Economic School, Moscow

ERNEST A. ZITSER

Ernest A. Zitser, Duke University, Durham 